Review

\title{
The Multifaceted Role of Curcumin in Cancer Prevention and Treatment
}

Muthu K. Shanmugam ${ }^{1}$, Grishma Rane ${ }^{1,2}$, Madhu Mathi Kanchi ${ }^{2}$, Frank Arfuso ${ }^{3}$, Arunachalam Chinnathambi ${ }^{4}$, M. E. Zayed ${ }^{4}$, Sulaiman Ali Alharbi ${ }^{4}$, Benny K. H. Tan ${ }^{1}$, Alan Prem Kumar ${ }^{1,2,3,5, *}$ and Gautam Sethi ${ }^{1,3,4, *}$

1 Department of Pharmacology, Yong Loo Lin School of Medicine, National University of Singapore, Singapore 117597, Singapore; E-Mails: phcsmk@nus.edu.sg (M.K.S.); a0095676@nus.edu.sg (G.R.); benny_tan@nuhs.edu.sg (B.K.H.T.)

2 Cancer Science Institute of Singapore, Centre for Translational Medicine, 14 Medical Drive, \#11-01M, Singapore 117599, Singapore; E-Mail: csikmm@nus.edu.sg

3 School of Biomedical Sciences, CHIRI Biosciences Research Precinct, Curtin University, Western Australia 6009, Australia; E-Mail: frank.arfuso@uwa.edu.au

4 Department of Botany and Microbiology, College of Science, King Saud University, Riyadh 11451, Saudi Arabia; E-Mails: dr.arunmicro@gmail.com (A.C.); mozayed@ksu.edu.sa (M.E.Z.); sharbi@ksu.edu.sa (S.A.A.)

5 Department of Biological Sciences, University of North Texas, Denton, TX 76203, USA

* Authors to whom correspondence should be addressed; E-Mails: csiapk@nus.edu.sg (A.P.K.); phcgs@nus.edu.sg (G.S.); Tel.: +65-6516-5456 (A.P.K.); +65-6516-3267 (G.S.);

Fax: +65-6873-9664 (A.P.K.); +65-6873-7690 (G.S.).

Academic Editor: Bharat B. Aggarwal

Received: 10 November 2014 / Accepted: 30 January 2015 / Published: 5 February 2015

Abstract: Despite significant advances in treatment modalities over the last decade, neither the incidence of the disease nor the mortality due to cancer has altered in the last thirty years. Available anti-cancer drugs exhibit limited efficacy, associated with severe side effects, and are also expensive. Thus identification of pharmacological agents that do not have these disadvantages is required. Curcumin, a polyphenolic compound derived from turmeric (Curcumin longa), is one such agent that has been extensively studied over the last three to four decades for its potential anti-inflammatory and/or anti-cancer effects. Curcumin has been found to suppress initiation, progression, and metastasis of a variety of tumors. These anti-cancer effects are predominantly mediated through its negative regulation of various 
transcription factors, growth factors, inflammatory cytokines, protein kinases, and other oncogenic molecules. It also abrogates proliferation of cancer cells by arresting them at different phases of the cell cycle and/or by inducing their apoptosis. The current review focuses on the diverse molecular targets modulated by curcumin that contribute to its efficacy against various human cancers.

Keywords: curcumin; inflammation; cancer; NF- $\kappa \mathrm{B}$

\section{What Is Curcumin?}

Turmeric is a rhizome from the herb Curcuma longa Linn, which was frequently cited in ancient medicinal texts of Ayurveda and in traditional Chinese medicine to be useful for the prevention and cure of a variety of human ailments. Dried turmeric powder is also used in sub-continental cooking and is the main ingredient in all forms of "curry" preparations. Turmeric powder is yellow pigmented and has numerous curcuminoids that include curcumin $(77 \%)$, demethoxycurcumin (17\%), and bisdemethoxycurcumin (3\%). Curcumin is a polyphenol (1,7-bis(4-hydroxy-3-methoxyphenyl)-1,6heptadiene-3,5-dione). Ayurvedic medicine clearly designates curcumin as an effective medicine for various disorders such as asthma, bronchial hyperactivity, allergy, anorexia, coryza, cough, sinusitis, and hepatic disease [1]. Extensive research on curcumin over decades with approximately 6850 publications has provided greater insight into its medicinal and health benefits. There are many reports of its anti-infectious [2], anti-oxidant [3], anti-inflammatory [4,5], hepatoprotective [6], cardioprotective [7], thrombosuppressive [8], anti-arthritic [9], chemopreventive, and anti-carcinogenic [10-12] properties. Curcumin has also been shown to modulate multiple cellular molecular targets [13,14]. Several alternative sources of curcumin and its analogues have been reported from other Curcuma species such as Curcuma mangga, Curcuma zedoaria, Costus speciosus, Curcuma xanthorrhiza, Curcuma aromatic, Curcuma phaeocaulis, Etlingera elatior, and Zingiber cassumunar [15]. Figure 1 depicts the various biological sources and chemical structure of curcumin.

\section{Reported Anti-Cancer Effects of Curcumin}

Cancer is a hyper-proliferative disorder where a normal cell loses its cellular homeostasis and begins to constitutively activate a plethora of genes that are involved in cell cycle, invasion, survival, metastasis, and angiogenesis. Curcumin is also a potent anti-inflammatory compound. Based on its distinct chemical properties, curcumin interacts with numerous extracellular and intracellular molecules that are actively involved in cancer initiation and progression, thereby inhibiting cancer progression [16-19]. Increasing evidence suggests that deregulated inflammatory pathways play a pivotal role in a multitude of chronic diseases, including cancer [20]. The mechanism by which chronic inflammation drives cancer initiation and progression is via increased production of pro-inflammatory mediators, such as cytokines, chemokines, reactive oxygen species (ROS), overexpression of oncogenes, cyclooxygenase (COX-2), matrix metalloproteinase (MMPs), intracellular signaling pathway mediators, transcription factors such as nuclear factor $\kappa \mathrm{B}(\mathrm{NF}-\kappa \mathrm{B})$, signal transducer and activator of transcription 3 (STAT3), protein kinase 
$\mathrm{B}(\mathrm{AKT})$, and activator protein 1 (AP1) that drive tumor cell proliferation, transformation, invasion, metastasis, angiogenesis, chemoresistance, and radioresistance [17,18,20-28].

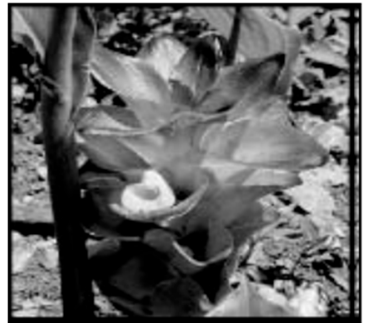

Curcuma aromatica

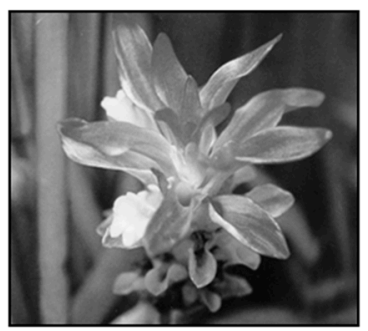

Curcuma Zedoaria

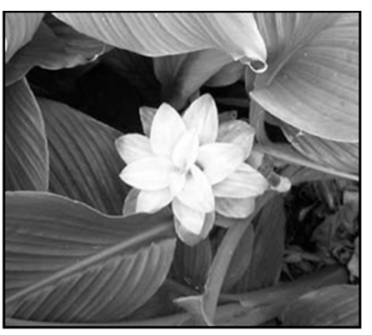

Curcuma Longa
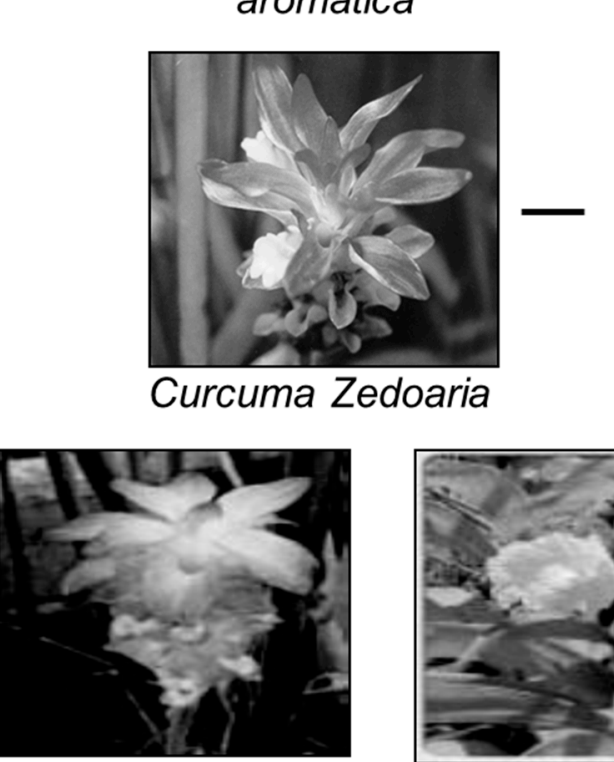

Curcuma xanthorrhiza

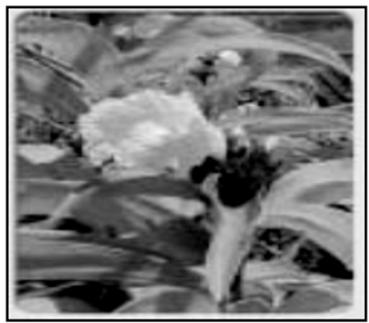

Costus speciosus
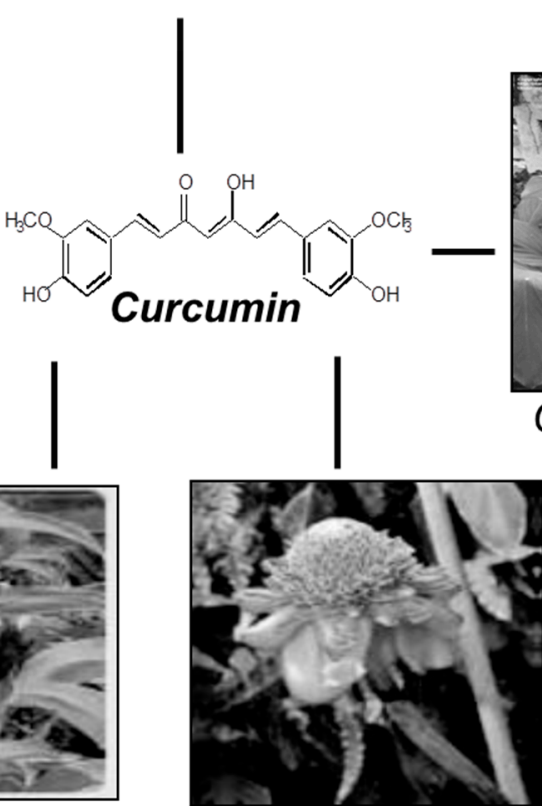

Etlingera elatior

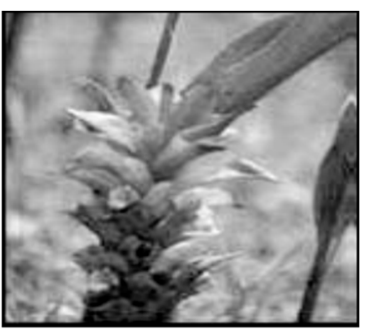

Curcuma

Phaeocaulis

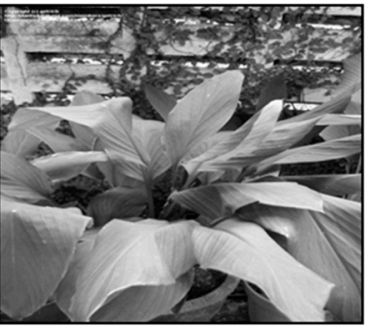

Curcuma Mangga

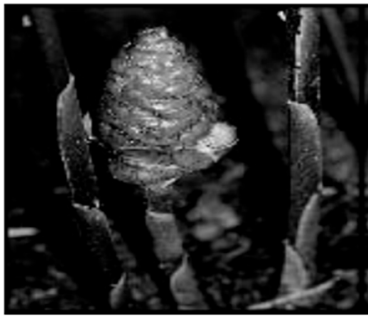

Zingiber

cassumunar

Figure 1. Biological sources and chemical structure of curcumin.

Overall, the various molecular targets modulated by curcumin are summarized in Figure 2. Numerous studies have also reported the inhibitory effects of curcumin on almost all types of tumor cells, such as cancers of the reproductive, digestive, lymphatic and immune, urinary, pulmonary, nervous, skeletal systems, and the skin. The inhibitory concentrations of curcumin have been found to range from $1 \mu \mathrm{M}$ to $100 \mu \mathrm{M}$ in these studies [29].

\section{Molecular Targets Modulated by Curcumin}

\subsection{Transcription Factors}

\subsubsection{Activator Protein (AP)-1}

The transcription factor AP-1 is known to express cancer-relevant genes that activate mitogenic, anti-apoptotic, and pro-angiogenic signals [30-33]. Members of the MAPK family such as ERK1/2 phosphorylate and activate AP-1 [34], causing up-regulation of CCND1 that encodes cyclin D1 [35,36]. 
AP-1 is often associated with tumor progression and the high levels of NF- $\mathrm{BB}$ and AP-1 expression seen in gliomas is in part responsible for increased chemoresistance and radioresistance [37].

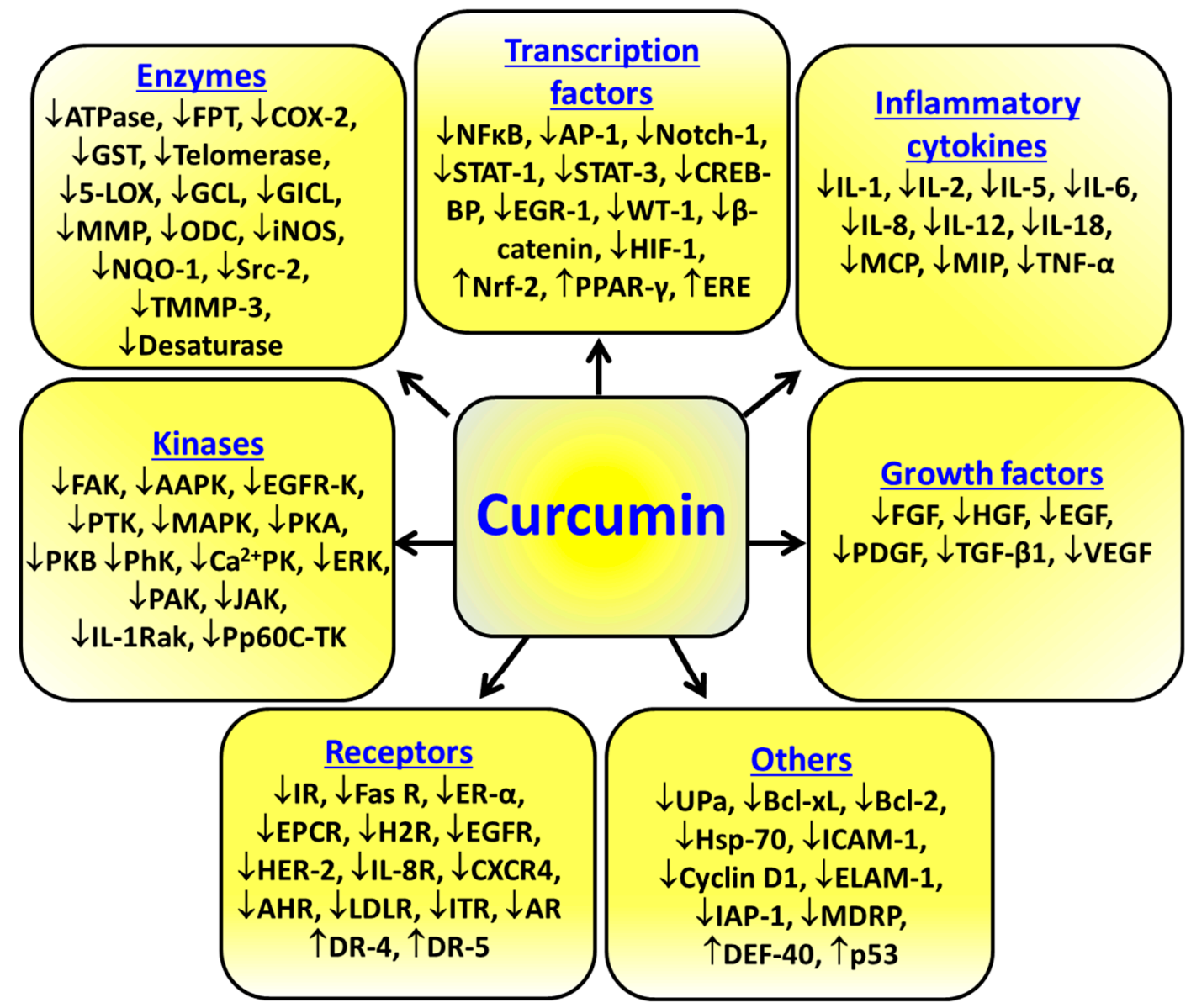

Figure 2. Molecular targets modulated by curcumin. $\downarrow$ Down-regulated targets; $\uparrow$ Up-regulated targets.

Curcumin has been shown to sensitize human and rat glioma cells to radiation treatment in T98G, U87MG, and T67 cells, and inhibit AP-1 and NF-kB signaling pathways [38]. Curcumin $(20 \mu \mathrm{M})$ inhibited TPA-stimulated PKC activity in human astroglioma cells and down-regulated pro-angiogenic AP-1 and MMP9 [39]. In human HCT-116 colon cancer cells, curcumin (10-25 $\mu \mathrm{M})$ inhibited PKC activation by inhibiting the release of $\mathrm{Ca}^{2+}$ from the endoplasmic reticulum [40,41]. In another study, curcumin was shown to suppress JNK activation induced by carcinogens [42]. Curcumin abrogated hydrogen peroxide-stimulated proliferation of LnCap prostate cancer cells through the suppression of AP-1 transcription factor [43]. Prusty and Das reported that curcumin down-regulated AP-1 in cervical cancer cells [44]. Therefore, inhibition of PKC activity by curcumin could inhibit neovascularization in tumors by unsettling pro-angiogenic signaling through the ERK-AP-1-MMP-9 pathway [29]. In the DMBA-induced hamster buccal pouch model of carcinogenesis, dietary turmeric (1\%) administered for 12 weeks reduced the DMBA-induced tumor burden by down-regulating Ras oncogene product p21 [45]. Interestingly, when Hepa1-6 cells were transfected with c-Met-CAT promoter constructs and then stimulated with HGF, there was rapid induction of AP-1 DNA binding activity. When these cells were incubated with curcumin, the c-Met promoter activity was abrogated [46]. 


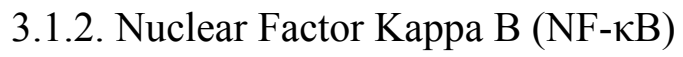

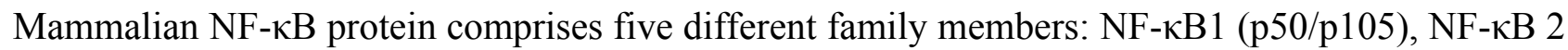
(p52/p100), RelA (p65), RelB, and c-Rel. All family members share the common Rel homology domain (RHD: 300aa), which helps in DNA binding and in interaction with I $\kappa \mathrm{Bs}$, the intracellular inhibitor of $\mathrm{NF}-\kappa \mathrm{B}[22,47-49]$. NF- $\mathrm{B}$ can be activated by numerous agents ranging from growth factors, oxidative stress inducers, viruses, gram-negative bacterial products, mitogens, pro-inflammatory cytokines, and environmental stress factors (such as ultraviolet light, $\mathrm{H}_{2} \mathrm{O}_{2}$, cigarette smoke, and asbestos), chemotherapeutic agents, and gamma radiation [50-52]. Upon activation by pro-inflammatory cytokines, such as tumor-necrosis factor-alpha (TNF- $\alpha$ ) and interleukin $1 \beta$ (IL-1 ), IkBs can be phosphorylated at two equivalent serine residues, S19 and S23, by both IKK $\alpha$ and $\beta[18,47,53]$. The phosphorylated NF- $\mathrm{KB}$ then migrates to the nucleus and initiates gene transcription of various oncogenic genes that suppress apoptosis but induce cell proliferation and transformation, invasion, metastasis, chemoresistance, radioresistance, and angiogenesis [22,24,50,54,55]. Interestingly, endogenous WIP1 phosphatase was show to be a negative regulator of NF- $\kappa B$ [56]. The active constitutive form of NF- $\mathrm{B}$ has been reported to occur in almost all cancers, and the ability of curcumin to suppress activation of $\mathrm{NF}-\kappa \mathrm{B}$ is of particular interest in cancer therapy [13,57].

The anti-cancer activity of curcumin was first demonstrated in the 1980's by Kuttan and colleagues [58,59]. In 1995, Singh and Aggarwal showed that curcumin exhibits its anti-inflammatory activity by suppressing NF- $\mathrm{BB}$ activity [60]. Research on curcumin has significantly increased over the years and approximately 7000 articles have been published till date, as indicated by NIH PubMed database [61]. Curcumin efficiently suppressed activation of NF- $\kappa$ B induced by various stimuli such as phorbol ester, TNF- $\alpha$, and hydrogen peroxide [60]. Subsequently, other researchers showed that curcumin inhibited the NF-אB pathway upstream kinases, IKK $\alpha$ and IKK $\beta[62,63]$. In another study, they showed that curcumin inhibited cigarette smoke-induced NF- $\kappa$ B activation in human lung epithelial cells [64], and also inhibited constitutive activation in head and neck cancer, multiple myeloma, and mantle cell lymphoma [65]. Interestingly, curcumin abrogated paclitaxel-induced NF- $\kappa$ B activation in breast cancer cells and inhibited lung metastasis in a breast cancer nude mouse model [66]. Recent studies have shown that down-regulation of NF- $\mathrm{B}$ led to suppressed expression of cyclin D1, COX-2, MMP9, and pro-MMP2 [67,68].

Curcumin inhibits the Notch signaling pathway in pancreatic cancer cells [69], and has been shown to be a potent proteasomal inhibitor [70], inhibiting the $20 \mathrm{~S}$ proteasome and inducing degradation of I $\kappa \mathrm{B} \alpha$ in colon cancers [71]. In addition, curcumin inhibited NF- $\kappa \mathrm{B}$-induced production of CXCL1 and CXCL2 in breast cancer cells [72]. Curcumin can abrogate NF- $\kappa \mathrm{B}$ pathway in multiple cancer cells [73], including breast cancer [74-81], colorectal cancer [82,83], human oral squamous carcinoma [84], human bladder cancer [85,86], cutaneous T-cell lymphoma [87,88], pancreatic cancer [89], head and neck squamous cell carcinoma [90,91], adenoid cystic carcinoma [92], glioblastoma [93,94], human tongue squamous cell carcinoma [95], human biliary cancer [96], medulloblastoma [97], gastric cancer [98], lymphoma [99,100], Myeloid-derived suppressor cells [101], ovarian cancer [102], T-cell and NFAT activation [103], rhabdomyosarcoma [104,105], esophageal adenocarcinoma [106,107], esophageal squamous cell carcinoma [108,109], human epidermoid carcinoma [110], prostate cancer [111-113], non-Hodgkin's lymphoma [114], Hodgkin's lymphoma [115], human Burkitt's lymphoma [116], 
and thyroid carcinoma [117], exemplifying curcumin as a potential chemopreventive, oncostatic, and anti-metastatic agent.

\subsubsection{Peroxisome Proliferator-Associated Receptor Gamma}

Peroxisome proliferator-associated receptor gamma (PPAR- $\gamma$ ) is a member of the nuclear receptor family [118]. Activation of PPAR- $\gamma$ has been identified to be involved in inducing differentiation and inhibiting proliferation of cancer cells [119-122]. Curcumin was reported to activate PPAR- $\gamma$ and inhibited the growth of Moser cells, with subsequent inhibition of cyclin D1 and EGFR gene expression [123]. In another study, curcumin activated PPAR- $\gamma$ in cholangiocarcinoma cell lines (KKU100, KKU-M156, and KKU-M213) and induced apoptosis in these cell lines [124]. Curcumin significantly inhibited proliferation in Eker rat-derived uterine leiomyoma cell lines (ELT-3) via activation of PPAR $\gamma$, where curcumin acted as a PPAR $\gamma$ ligand and, in the presence of a PPAR $\gamma$ antagonist, the inhibitory effect of curcumin was reversed [125].

\subsubsection{Signal Transducer and Activator of Transcription (STAT)}

The STAT family consists of seven members: STAT1, STAT2, STAT3, STAT4, STAT5a, STAT5b, and STAT6. They range in size from 750 to 850 amino acids [28,126,127]. Among other STAT family proteins, STAT3 has received considerable attention during the last decade since it is a convergent point for a number of oncogenic signaling pathways, and controls intra-cellular signal transduction pathways of several pro-inflammatory cytokines and growth factors [128,129]. STAT3 can be activated by IL-6, EGFR, PDGF, leukemia inhibitory factor (LIF), oncostatin M, and the ciliary neurotrophic factor (CNTF) family of cytokines, which are all known to mediate their signal through the gp130 protein [130-133]. IL-6 is a key event in tumorigenesis, with high levels associated with hepatocellular carcinoma (HCC) [134].

Constitutively activated STAT3 has been implicated in multiple cancers such as head and neck cancer [135], leukemias [136], lymphomas [137], and multiple myeloma [138], making it a potential target for cancer therapy. Under normal physiological conditions, STAT3 contributes to cell survival and growth, and prevents apoptosis by up-regulating the expression of anti-apoptotic proteins such as Bcl-2 and Bcl-xL. In addition, STAT3 also activates VEGF expression thereby increasing angiogenesis. In a study by Bharti et al., curcumin was shown to inhibit interleukin IL-6 induced STAT3 phosphorylation and consequent STAT3 nuclear translocation in multiple myeloma cells [138]. Curcumin was more efficient and more potent than the well-characterized JAK2 inhibitor AG490. In addition, dexamethasone-resistant multiple myeloma cells were found to be sensitive to curcumin [138]. In a subsequent follow-up study, Bharti et al., reconfirmed their earlier findings by testing the effect of curcumin on $\mathrm{CD} 138^{+}$cells derived from multiple myeloma patients. Curcumin substantially inhibited constitutively active STAT3 in these cells $[138,139]$. In primary effusion lymphoma cells, curcumin inhibited cell proliferation and induced caspase-dependent apoptosis in a dose-dependent manner via suppression of the JAK/STAT3 pathway [140].

In the HTLV-I-transformed T cell leukemia lines, MT-2, HuT-102, and SLB-1, which express constitutively phosphorylated JAK2, TYK2, STAT3, and STAT5 signaling proteins, curcumin induced a dose-dependent decrease in JAK and STAT phosphorylation, resulting in the induction of 
growth-arrest and apoptosis in T cell leukemia [141]. In another study by Charkravarti et al., curcumin inhibited constitutive and IL-6 induced STAT3 phosphorylation in a dose and time dependent manner and induced apoptosis of HNSCC cells [142]. Attenuation of JAK-STAT3 phosphorylation by curcumin in K562 chronic leukemia cells resulted in suppression of JAK2, cyclin D1, and $v$-src gene expression [143]. In multidrug-resistant breast cancer model, MCF-7 and MCF-7R (which lacks estrogen receptor alpha $[\mathrm{ER} \alpha]$ and overexpresses p-glycoprotein, different IAPs ([inhibitor of apoptosis proteins] and COX-2, curcumin inhibited cell proliferation and induced apoptosis, and the effect was more potent in the multidrug-resistant MCF-7R compared to its parental MCF7 cells [144]. In a Hodgkin's lymphoma cell line, curcumin induced cell-cycle arrest and induced apoptosis [145]. In numerous studies using various cancer cell lines, curcumin was shown to inhibit cellular proliferation by down-regulating the JAK-STAT3 pathway in chronic lymphocytic leukemia B cells [146], human multiple myeloma U266 cells [147], pancreatic cancer cells [148,149], ovarian and endometrial cancer cells [150,151], melanoma cells [152,153], cutaneous T-lymphoma cells [87], malignant gliomas [154,155], myeloid-derived suppressor cells [101], lung cancer [156,157], and hepatocellular carcinoma [158]. Thus, curcumin presents proven potential as an effective inhibitor of STAT3 phosphorylation and of downstream gene transcription.

\subsubsection{Wnt/ $\beta$-catenin}

Signaling by Wnt glycolipoproteins is one of the fundamental mechanisms that direct cell proliferation and tissue homeostasis [159]. Mutations in the Wnt pathway are often linked to cancer and other diseases [160]. Wnt, in association with the transcriptional co-activator $\beta$-catenin, controls the development of gene expression programs. De-regulated Wnt/ $\beta$-catenin is commonly observed in colon cancer [161]. Curcumin treatment inhibits both Wnt and cell-cell adhesion pathways, resulting in induction of apoptosis in HCT-116 colon cancer cells [162-164]. In a study using colon cancer cells, it was shown that curcumin suppresses the Wnt/ $\beta$-catenin pathway through down-regulation of the transcriptional co-activator p300 [165]. In human breast cancer cells, curcumin was found to effectively inhibit the expression of several Wnt/ $\beta$-catenin pathway components such as disheveled, beta-catenin, cyclin D1, and slug in both MCF-7 and MDA-MB-231 breast cancer cell lines [166]. Aberrant Wnt/ $\beta$-catenin signaling promotes osteosarcoma tumorigenesis and metastasis. Treatment with curcumin reduced osteosarcoma cell proliferation, invasion and migration, and induced apoptosis by suppressing the Wnt/ $\beta$-catenin pathway [167]. In LnCap prostate cancer cells, curcumin treatment inhibited androgen receptor expression and inhibited $\mathrm{Wnt} / \beta$-catenin both in cytoplasmic as well as nuclear extracts and in whole cell lysates [168]. In yet another study using androgen-independent prostate cancer cells, curcumin was found to decrease the level of Tcf-4, CBP, and p300 proteins that are implicated in the Wnt transcriptional complex, leading to the decrease of $\beta$-catenin/Tcf-4 transcriptional activity and of the expression of $\beta$-catenin target genes (cyclin Dl and c-myc) [169]. In another study, curcumin was found to negatively regulate Wnt/ $\beta$-catenin pathway by activating protein kinase D1 in prostate cancer cells [170]. In human hepatocellular carcinoma, curcumin inhibits proliferation and induces apoptosis by suppressing the $\mathrm{Wnt} / \beta$-catenin pathway [171]. In a recent study using meduloblastoma cell lines, attenuation of the $\mathrm{Wnt} / \beta$-catenin pathway by curcumin was due to the suppression of nuclear $\beta$-catenin [172], 
and in non-small cell lung cancer, curcumin inhibited metastasis-associated protein 1-mediated inactivation of the $\mathrm{Wnt} / \beta$-catenin pathway [173].

\subsubsection{Nrf-2}

Upon redox-dependent stimuli, the transcription factor Nrf-2-Keap interaction enables Nrf-2 to translocate to the nucleus and bind to the antioxidant-response element (ARE) and initiate transcription of genes encoding for antioxidant and detoxifying enzymes via heme oxygenase-1 (HO-1), NADPH quinone oxidoreductase-1, and glutathione [174,175]. Several strategies for induction of Nrf-2 activity to prevent cancer development have been employed over the last couple of years [176]. Curcumin treatment was shown to increase the expression of transcription factor Nrf-2, a key transcriptional regulator of antioxidant and detoxifying enzymes in renal epithelial cells [177]. Nrf-2 has been shown to be necessary for the up-regulation of genes involved in oxidative stress, such as glutathione $S$-transferase superoxide dismutase-containing ARE [178]. Curcumin activates ARE-mediated gene expression in human monocytes via PKC delta, upstream of p38 and Nrf-2 [179].

In human hepatocytes, curcumin induced ROS generation, activated Nrf-2 and MAP kinases, inhibited phosphatase activity in hepatocytes and induced HO-1 [180]. Curcumin showed chemopreventive effect against prostate cancer in TRAMP C1 cells through epigenetic modification of the Nrf-2 gene, with subsequent induction of the Nrf-2-mediated anti-oxidative stress cellular defense pathway [181]. Over-expression of Flap endonuclease 1 (Fen1), a DNA repair-specific nuclease, is involved in the development of breast cancer. In another recent study, Chen et al., recently showed that curcumin can inhibit breast cancer cell proliferation through Nrf-2 mediated down-regulation of FEN-1 expression [182].

\subsubsection{Pro-Inflammatory Cytokines}

Tumor Necrosis Factor-alpha (TNF- $\alpha$ ) and Interleukins

TNF- $\alpha$ has been shown to mediate tumor initiation, promotion, and metastasis $[183,184]$. The pro-inflammatory effects of TNF- $\alpha$ are due primarily to its ability to activate NF- $\kappa$ B. Almost all cell types, when exposed to TNF- $\alpha$, activate NF- $\mathrm{BB}$, leading to expression of inflammatory genes such as COX-2, 5-LOX, cell adhesion molecules, inflammatory cytokines, chemokines, and inducible nitric oxide synthase [185]. TNF- $\alpha$ also functions as a growth factor for most tumor cells [186,187]. Curcumin suppresses the expression of TNF- $\alpha$ at both the transcriptional and post-transcriptional levels. TNF- $\alpha$ increased the expression of intracellular adhesion molecule-1 (ICAM-1), vascular cell adhesion molecule-1 (VCAM-1), and endothelial leukocyte adhesion molecule-1 (ELAM-1) in human umbilical vein endothelial cells. Pre-treatment with curcumin inhibited the TNF- $\alpha$ induced adhesion of monocytes to vascular endothelial cells [188]. Curcumin (10 and 100 micromol/1) inhibited TNF- $\alpha$ secretion from trypsin or activating peptide-stimulated human leukemic mast cells [189]. The combination of curcumin and sulforaphane inhibited the inflammatory markers iNOS, COX-2, prostaglandin E2 (PGE2), TNF- $\alpha$, and interleukin-1 (IL-1) [190]. In another study, curcumin was shown to down-regulate the expression of TNF- $\alpha$ mRNA in K562 leukemia cells [191]. 
In an orthotopic mouse model of lung cancer using intravenously injected Lewis lung carcinoma (LLC) cells, 5\% w/w dietary curcumin exerted physiological changes in lung tissues by significantly decreasing LPS-induced TNF- $\alpha$ production in lungs [192]. Orally bioavailable curcumin blocks TNF- $\alpha$ action and secretion in in vitro models, in animal models, and in humans [193]. In breast epithelial and breast cancer cells, curcumin reversed TNF- $\alpha$ induced Warburg-like metabolism [194]. The anti-cancer effect of curcumin against lymphoma has been reported previously. However, in this study they reported that long-term use of curcumin may attenuate cancer progression via the down-regulation of TNF- $\alpha$ and of IL-6 modulated by E26 transformation-specific protein (ETS) and NF- $\mathrm{B}$ [195]. In general, various plant-derived polyphenols were shown to suppress TNF- $\alpha$ activated inflammatory pathways in both in vitro and in vivo models of cancer [196]. Curcumin can inhibit the expression of both TNF- $\alpha$ mRNA and TNF- $\alpha$ protein in mantle cell lymphoma cell lines. Suppression of TNF- $\alpha$ by curcumin led to the abrogation of NF- $\kappa \mathrm{B}$ activation and cell proliferation, as was the case when TNF- $\alpha$ secretion was neutralized using an anti- TNF- $\alpha$ antibody [65]. Curcumin prevented both cadmium-induced IL- 6 and IL-8 secretion by human airway epithelial cells [197].

\subsubsection{Inflammatory Enzymes}

Inducible Nitric Oxide Synthase (iNOS), Cyclooxygenase-2 (COX-2), Lipooxygenase (LOX)

COX-2, LOX, and iNOS are important enzymes that mediate inflammatory processes. Curcumin is a known, potent anti-inflammatory agent that prevents tumor progression and exerts chemopreventive effects on carcinogenesis [198,199]. Inducible nitric oxide synthase (iNOS) is an inflammation-induced enzyme that catalyzes the production of nitric oxide (NO), a molecule that may lead to carcinogenesis. Curcumin inhibited iNOS expression in ex vivo cultured BALB/c mouse peritoneal macrophages in a concentration-dependent manner [200]. Curcumin suppressed lipopolysaccharide (LPS)-induced expression of iNOS and COX-2 and prevented colon carcinogenesis [201]. Curcumin reduced cholangiocarcinogenesis in hamsters via reduction in the expression of pro-inflammatory proteins such as COX-2 and iNOS [124]. In combination with polyunsaturated fatty acids, curcumin produced a synergistic effect and inhibited the proliferation of RAW 264.7 macrophages by suppressing iNOS, COX-2, 5-lipoxygenase (5-LOX), and cPLA(2) [202].

\subsubsection{Oncogenic Kinases}

Functional activation of key protein kinases, including IкB kinases and mitogen-activated protein kinases (MAPKs) such as p38 MAPK, JNK1/2, and extracellular signal-regulated kinase 1/2 (ERK1/2), all of which are involved in activating key transcription factors such as NF- $\kappa \mathrm{B}$ and AP-1, serve as important target molecules for cancer prevention and therapy [203]. Protein kinases and growth factors are also targets of curcumin, which has been shown to down-regulate the activity of ERK1/2 in pancreatic and lung adenocarcinoma cells [204]. Curcumin has also been shown to inhibit the PI3 kinase/AKT pathway in malignant glioma cells [205]. Curcumin inhibits a plethora of kinases including phosphorylase kinase, protein kinase $\mathrm{C}$, protamine kinase, auto-phosphorylation-activated protein kinase, and pp60c-src tyrosine kinase [13,18]. Curcumin-induced apoptosis of neutrophils was mediated via activation of p38 MAPK and induction of caspase-3 [206]. In experimental colitis, curcumin 
inhibited p38 MAPK [207]. In another study by Chen et al., curcumin suppressed JNK activation induced by various stimulants such as ionomycin, anisomycin, phorbolmyristate acetate, $\gamma$-radiation, TNF- $\alpha$, UV-C, and sodium orthovanadate [42].

\subsection{Growth Factor Induced Signaling Cascades}

ErbB-2 (avian erythroblastosis oncogene B) or HER2/neu is a member of the epidermal growth factor receptor (EGFR) family and plays an important role in the pathogenesis of breast cancer. It is a cell membrane tyrosine kinase receptor that binds to growth factors and mediates cell proliferation and differentiation. HER2/neu is over-expressed in breast cancer [208], and both HER2 and EGF receptors stimulate proliferation of breast cancer cells. Curcumin suppressed EGFR signaling in prostate cancer cells by inhibiting ligand-induced activation of EGFR and its intrinsic tyrosine kinase activity [209]. In colorectal cancer cells, Caco-2 and HT-29, curcumin down-regulated the transcription factor, Egr1, and the expression of EGFR, thereby inhibiting colorectal cancer cell growth [10]. In non-small cell lung cancer (NSCLC), activating mutations of EGFR are responsive to erlotinib, an EGFR antagonist, while somatic mutations of EGFR are non-responsive. Curcumin significantly increased the cytotoxicity of erlotinib -resistant H1975 and H1650 NSCLC cells, and enhanced erlotinib-induced apoptosis, down-regulated the expression of EGFR, p-EGFR, and survivin in erlotinib-resistant NSCLC cells [210].

Curcumin improved the efficiency of gefitinib in the drug-resistant NSCLC cells both in vitro and in vivo by inducing EGFR degradation and modulating p38 activation [211]. In another study using human bronchial epithelial (HBE) Beas-2B cells and lung cancer A549 cells, curcumin decreased EGFR expression [212]. Curcumin modulated the migratory and invasive ability of the highly metastatic mouse hepatoma Hca-F cells, through a novel mechanism involving inactivation of Cav-1 and EGFR signaling pathways [213]. Curcumin was shown to inhibit functional interaction between integrin $\alpha 6 \beta 4$ and growth factor receptor, EGFR, a key event in breast carcinoma cell motility and invasion [214]. In colon cancer cells treated with 5-FU plus oxaliplatin (FOLFOX), the addition of curcumin down-regulated activation of EGFR, HER-2, IGF-1R, and AKT [215,216]. Curcumin attenuated EGF-induced aquaporin water channels in cells from the human ovarian cancer cell line, $\mathrm{CaOV} 3$, and thereby inhibiting cell migration and metastatic potential [217].

\subsection{Other Protein Kinases and Inflammatory Mediators}

\subsubsection{Cyclin D1}

Cyclin D1 is a subunit of Cdk4 and Cdk6, and is over-expressed in a multitude of cancers such as lung, liver, head and neck, prostate, breast, colon, and multiple myeloma cells [13]. The expression of cyclin D1 is mainly controlled through the NF- $\kappa$ B pathway. Suppression of the NF- $\kappa$ B pathway leads to suppression of cell cycle progression mediated by cyclin D1. Curcumin was shown to down-regulate cyclin D1 [218]. Curcumin inhibited cell proliferation and induced G2/M cell cycle arrest in HCT-116 cells. Immunoblotting analysis showed that cyclin D and E levels declined while cyclin B levels were unchanged. Curcumin inhibited cell proliferation and induced G2/M arrest in HCT-116 cells. Investigation of the levels of cyclins E, D, and B by immunoblotting analysis showed that cyclin B level was unaffected, whereas cyclin D and E levels declined with curcumin treatment [219]. In immortalized 
human endothelial-like cells (ECV304), curcumin inhibited cell proliferation and induced G0/G1 and/or G2/M phase cell cycle arrest, up-regulated cyclin-dependent kinases, p21WAF1/CIP1, p27KIP1, and p53, and slightly down-regulated cyclin B1 and cdc2 [220].

Curcumin can also down-regulate p21WAF1/CIP1 expression in prostate cancer cells [221]. In four MYCN-amplified neuroblastoma cell lines, with wild-type or mutant p53, curcumin induced p21WAF1/CIP1 [222]. In another study, curcumin was reported to up-regulate cyclin dependent kinase inhibitors p21 and p27 in multiple tumor cell lines [16]. Moreover, Schaaf et al., (2009) found that curcumin suppressed the proliferation of 25 human pituitary adenocarcinoma cells by inhibiting cyclin D1 and cyclin-dependent kinase 4 and induced G2/M cell cycle arrest [223]. Curcumin enhanced the anti-proliferative effect of mitomycin $\mathrm{C}$ and induced cell cycle arrest, inhibited cyclin D1, cyclin $\mathrm{E}$, cyclin A, cyclin-dependent kinase 2 (CDK2) and CDK4, along with the induction of the cell cycle inhibitors p21 and p27 in MCF-7 cells [224]. In lung cancer cells, curcumin treatment inhibited cell proliferation, which was associated with up-regulation of p27 and p21, and down-regulation of cyclin D1 [225].

\subsection{2. $\mathrm{p} 53$}

p53 inactivation and NF- $\kappa \mathrm{B}$ activation are commonly observed in a variety of cancers and play an important role in cancer progression [226,227]. It has been shown that curcumin possesses dual activities such as activation of p53 and inhibition of NF- $\mathrm{kB}$ thereby inducing apoptosis. Curcumin induces p53-dependent apoptosis in basal cell carcinoma [228]. Zheng et al., showed that, curcumin up-regulated p53 in human melanoma cells [68]. In the breast cancer cell line MCF7, curcumin-induced apoptosis was accompanied by an increase in p53 level, increased DNA-binding activity, and delayed increase in the effector Bax expression [229]. In a neuroblastoma cell line, curcumin treatment transiently up-regulated p53 expression and induced nuclear translocation of p53, followed by induction of p21 (WAF-1/CIP-1) and Bax expression [222]. In mammary epithelial carcinoma cells, curcumin was reported to induce apoptosis by up-regulating p53 [230]. Curcumin up-regulated p53 in HT-29 colon cancer cells [231], and, in combination with oxaliplatin, produced a 16-fold induction of p53 protein in both p53wt and p53 mutant colorectal tumors [232]. Curcumin also enhanced expression of p53 molecule in tumor tissue, and modulated the apoptotic pathway in colorectal cancer cells [233], ovarian cancer [234], cisplatin-resistant ovarian cancer [235] and induced the expression of FOXO3a and p53 in nasopharyngeal carcinoma [236] by serine phosphorylation of p53 in a concentration- and time-dependent manner. Interestingly, curcumin down-regulated MDM2 independently of p53 in PC3 prostate cancer cells [237], while it was shown to up-regulate p53 protein expression in LnCap prostate cancer cells [238]. Curcumin induced apoptosis of human glioma cells in a p53-dependent manner followed by induction of p21 WAF-1/CIP-1 and ING4 [239]. In another study using human leukemia cells, curcumin-induced apoptosis was mediated by up-regulation of p53 and prolonged the life span of tumor bearing mice [240]. In bile duct cancer, curcumin increased p53 and Bax protein levels and was associated with marked oxidative stress and apoptosis [241]. In human renal carcinoma Caki cells, curcumin enhanced dual PI3K/Akt and mTOR inhibitor NVP-BEZ235-induced apoptosis through p53-dependent Bcl-2 mRNA down-regulation at the transcriptional level and Mcl-1 protein down-regulation at the post-transcriptional level [242]. Similarly, a small molecule compound nutlin-3 showed dual activity by simultaneously 
activating p53 and suppressing NF- $\mathrm{B}$ [243]. Interestingly, curcumin was found to down-regulate p53 expression in lung cancer cells and induced apoptosis independent of p53 [244]. Bush JA et al., (2001) reported a different mechanism of action of curcumin. In their study, they showed that curcumin induced apoptosis in human melanoma cells through the Fas/caspase-8 pathway independent of p53, and also that curcumin did not induce p53 in these cells [245]. In both MDA-MB-231 breast cancer cells [246], and in HCT-15 colorectal cancer cell line, curcumin was found to down-regulate p53 expression [247]. Curcumin induced p53-independent apoptosis in ovarian carcinoma cells that involved p38 MAPK activation [248]. Another study demonstrated that when curcumin was used in combination with trichostatin, it down-regulated p53 expression in breast cancer cells [249]. These contrasting effects of activation or suppression of p53 in various cancer cells by curcumin warrant further investigation.

\subsubsection{Adhesion Molecules}

Leukocyte recruitment by endothelial cells and their following movement from the vasculature into the tissue play major roles in inflammation-driven cancers. Treatment of vascular endothelial cells with TNF- $\alpha$ induced adhesion of monocytes to the vasculature due to increased expression of intracellular adhesion molecule-1 (ICAM-1), vascular cell adhesion molecule-1 (VCAM-1), and endothelial leukocyte adhesion molecule-1 (ELAM-1). Pre-treatment of vascular cells with curcumin inhibited monocyte adhesion with a concomitant decrease in ICAM-1, VCAM-1, and ELAM-1 expression, and inhibited cellular migration and invasion of SK-Hep-1 hepatocarcinoma cells $[188,250]$ and small cell lung cancer cells [157]. Matrix metalloproteinases (MMPs) are metal-dependent endopeptidases capable of degrading components of the extracellular matrix. MMPs are involved in chronic diseases such as cancers [251]. In human non-small cell lung carcinoma cells, curcumin suppressed cigarette smoke-induced MMP9 secretion by inhibiting the NF- $\kappa$ B pathway [64]. Curcumin also inhibited MMP9 in a variety of cancers such as prostate cancer [113], colon cancer [252], human promyelocytic leukemia [253], breast cancer [254], human laryngeal squamous carcinoma [255], metastatic colorectal cancer [256], U373 cells [257], lung cancer [258,259], nasopharyngeal carcinoma [260] and liver metastasis from colorectal cancer [261].

\subsection{In Vivo Studies}

Curcumin has been tested in numerous animal models of cancer and on almost all types of organ-specific cancers, including breast [262,263], oral [264], head and neck [265,266], hepatocellular carcinoma [267], pancreatic [268,269], prostate [270-272], colon [273,274], gastric [275], as well as multi-drug resistant cancer cells [276], cancer stem cells [277], and in a variety of other cancers as well as in chemoprevention, and chemoresistance [17,278-283]. The in vivo molecular targets of curcumin have been excellently reviewed previously [284-288]. Figure 3 clearly illustrates the potential role of curcumin in negatively regulation tumor initiation, progression and metastasis. 


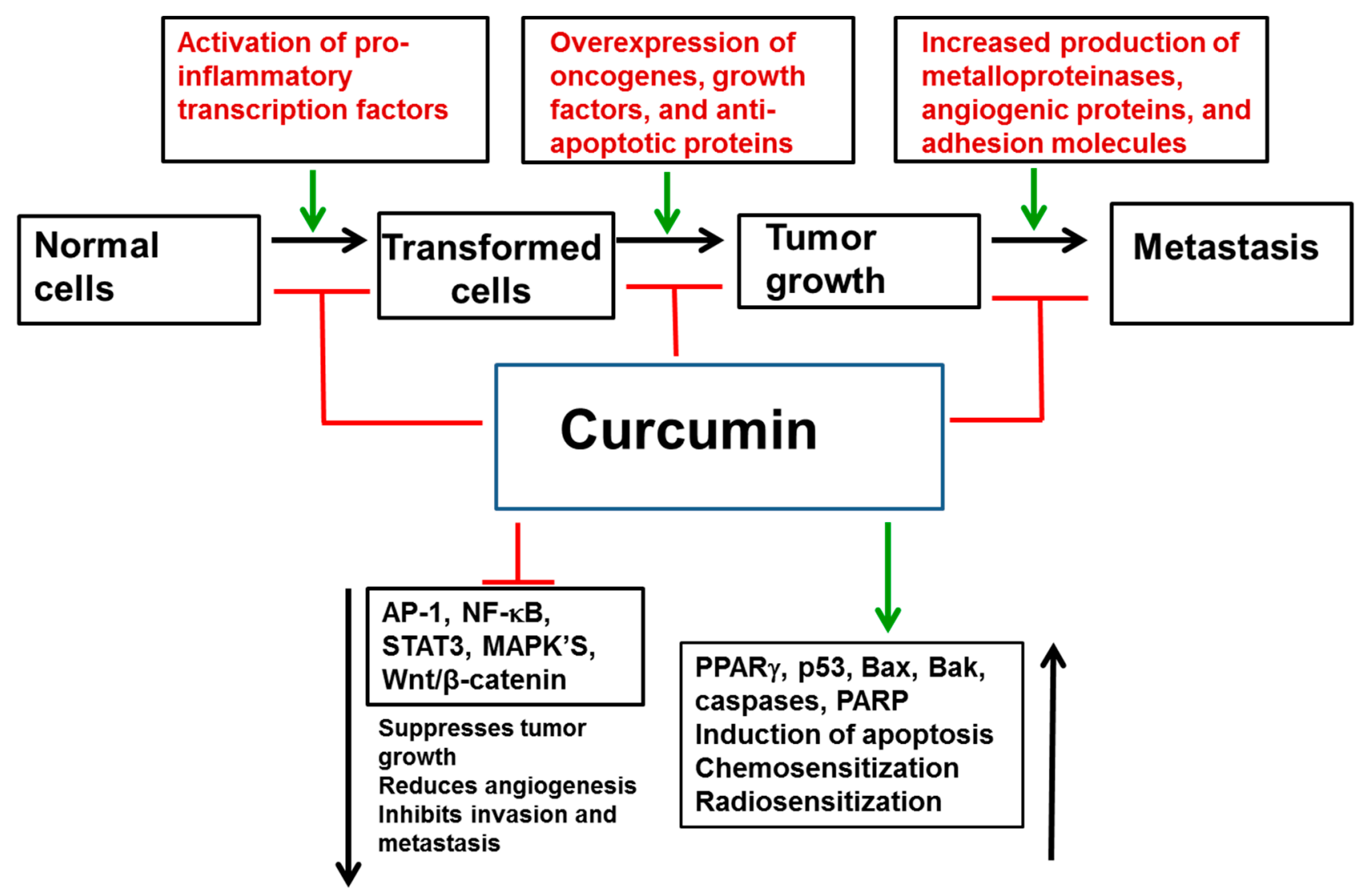

Figure 3. Potential anti-cancer functions of curcumin.

\subsection{Clinical Trials with Curcumin}

Curcumin as a therapeutic has been used for thousands of years but it was not until 1937 that Oppenheimer carried out the first clinical trial of curcumin against cholecystitis [61]. However, it was not until 1987 that the anti-cancer property of curcumin was evidenced by Kuttan et al. [59], where topical application of curcumin proved to be effective against external cancerous lesions. The multifaceted role of curcumin has been demonstrated in various human clinical trials over the past quarter century against many diseases including cancer, cardiovascular disease, diabetes, oral lichen planus, arthritis, and $\beta$-thalassemia. In particularly, the anti-cancer potential of curcumin has been successfully exhibited in various types of cancers namely oral, lung, breast, prostate, pancreatic, colorectal, multiple myeloma and head and neck squamous cell carcinoma. With safety and efficacy proven in more than 65 clinical trials and an additional 35 on-going trials [193], the use of curcumin as a supplement has already been approved in many countries such as the USA, South Africa, India, Nepal, Pakistan, Japan, Korea, China, Thailand, and Turkey. In an attempt to increase its bioavailability, several curcumin formulations have been developed such as powder, tablets, capsules, liposomal encapsulation, emulsions, and nanoparticles [289-291]. Apart from being effective by itself, curcumin also functions excellently in combination with various other compounds, such as docetaxel, acetylcysteine, gemcitabine, mesalamine, sulfasalazine, quercetin, pantoprazole, prednisone, bioperine, piperine, lactoferrin, and soy isoflavones [193]. Interestingly, the ramifications of curcumin at the molecular level have also been observed in human trials on the targets described in this review, including NF- $\mathrm{kB}$, STAT3, COX-2, phosphoryl kinase, prostaglandin E2, prostate-specific antigen, transforming growth 
factor- $\beta$, adhesion molecules, pro-inflammatory cytokines, apoptotic proteins, ET-1, 5-LOX, HO-1, C-reactive protein, creatinine, AST, ALT, and triglycerides [193] Numerous pilot clinical studies as well as phase I and II clinical trials of curcumin have been conducted to investigate its anti-cancer potential. These have been summarized in Table 1 and discussed in brief below:

\section{(a) Cancer Lesions}

The first phase I clinical trial to test the toxicity, pharmacokinetics, and biological effective dose of curcumin was carried out by Cheng et al., in 2001 [292]. Twenty-five patients who had either one of the following pre-malignant high cancer risk conditions were included: urinary bladder cancer, arsenic Bowen's disease of skin, uterine cervical intraepithelial neoplasm (CIN), oral leukoplakia, and intestinal metaplasia of the stomach. An escalating oral dose of 500, 1000, 2000, 4000, 8000, and 12,000 mg was tried and treatment-related toxicity was not observed up to $8000 \mathrm{mg} /$ day. Higher doses were found to be unacceptable to the patients, primarily due to bulky volume of the drug. Peak serum curcumin concentration was reached $1-2 \mathrm{~h}$ after intake, while it was undetectable in urine. Histologic improvement of pre-cancerous lesions was observed in one of the two resected bladder cancer patients, two out of six Bowen's disease patients, one out of four CIN patients, two out of seven oral leukoplakia patients, and one out of six patients with gastrointestinal metaplasia. Unfortunately, frank malignancies developed in one CIN patient and in one oral leukoplakia patient. Thus, in this study, apart from non-toxicity, the chemopreventive potential of curcumin against cancerous lesions was also demonstrated. In another randomized, double blind, placebo-controlled study, the efficacy of curcuminoids was evaluated in 100 patients with oral lichen planus. $2000 \mathrm{mg}$ of curcuminoids or placebo was given every day for 7 weeks and $60 \mathrm{mg} /$ day prednisone was given in the first week [293]. However, the trial was ended prematurely because the interim analysis predicted less than a $2 \%$ chance of better outcome in the curcuminoid group compared to placebo. The differences in the results of these two studies could be possibly attributed to the difference in the preparation of the curcumin dose. In a more recent study by Rai et al., $1000 \mathrm{mg}$ curcumin tablet was given daily for 7 days to patients with oral leukoplakia, oral submucous fibrosis, or lichen planus, and also to healthy subjects (25 participants in each group) [294]. Serum and salivary vitamin $\mathrm{C}$ and $\mathrm{E}$ levels improved and MDA while 8-hydroxydeoxyguanosine (8-OHdG) levels decreased. In addition, these changes were associated with a reported decrease in pain. In a randomized, double blind, placebo controlled trial where 20 subjects were given $6000 \mathrm{mg} /$ day of curcumin in three doses for 14 days, subjects showed improvement in clinical symptoms with a decrease in erythema, ulceration, and Modified Oral Mucositis Index (MOMI) [295]. 
Table 1. Summary of clinical trials with curcumin in various cancers.

\begin{tabular}{|c|c|c|c|c|c|c|}
\hline Serial & Study & $\begin{array}{c}\text { Number } \\
\text { of Patients }\end{array}$ & Health Condition & Dose & Outcome & Reference \\
\hline 1 & Double blind crossover & 62 & Cancer lesions & Topical ointment & Symptomatic relief to patients & [59] \\
\hline 2 & Pilot study & 16 & Lung cancer & $\begin{array}{l}1500 \mathrm{mg} / \text { day; } \\
30 \text { days (turmeric) }\end{array}$ & Urinary excretion of mutagens was decreased in smokers & [296] \\
\hline 3 & Pilot study & 58 & Cancer lesions & $\begin{array}{l}3600 \mathrm{mg} / \text { day; } 3 \text { months } \\
\text { (turmeric) }\end{array}$ & $\begin{array}{l}\text { Micronuclei number in mucosal cells and circulating } \\
\text { lymphocytes decreased }\end{array}$ & [297] \\
\hline 4 & Prospective Phase I trial & 25 & Cancer lesions & $8000 \mathrm{mg} /$ day; 3 months & Histologic improvement of precancerous lesions & [292] \\
\hline 5 & Prospective Phase I trial & 15 & Colorectal cancer & 36-180 mg; 4 months & Decrease in glutathione S-transferase activity & [298] \\
\hline 6 & Phase I trial & 12 & $\begin{array}{l}\text { Hepatic metastases from } \\
\text { colorectal cancer }\end{array}$ & 450-3600 mg/day; 1 week & $\begin{array}{l}\text { Low bioavailability of oral dose such that the dose of } \\
\text { curcumin required to exert its pharmacological activity at } \\
\text { hepatic level is not feasible in humans }\end{array}$ & [299] \\
\hline 7 & Phase I trial & 15 & Colorectal cancer & $\begin{array}{l}450-3600 \mathrm{mg} / \text { day; } \\
4 \text { months oral dose }\end{array}$ & $\mathrm{PGE}_{2}$ production reduced & {$[300]$} \\
\hline 8 & Phase I trial & 12 & Colorectal cancer & 450-3600 mg/day; 7 days & $\mathrm{M}_{1} \mathrm{G}$ levels decreased & [301] \\
\hline 9 & Pilot study & 5 & $\begin{array}{l}\text { Colorectal cancer (Familial } \\
\text { adenomatous polyposis) }\end{array}$ & $\begin{array}{l}1440 \mathrm{mg} / \text { day; } 6 \text { months, } \\
\text { combined with quercetin }\end{array}$ & $\begin{array}{c}\text { The number and size of polyps reduced without any } \\
\text { significant toxicity }\end{array}$ & [302] \\
\hline 10 & Prospective Phase I trial & 24 & Healthy volunteers & $\begin{array}{l}\text { 500-1200 mg; single oral } \\
\text { dose }\end{array}$ & $\begin{array}{l}\text { Overall well tolerated but } 30 \% \text { subjects had minor adverse } \\
\text { events }\end{array}$ & [303] \\
\hline 11 & $\begin{array}{l}\text { Randomized, placebo } \\
\text { controlled, double blind }\end{array}$ & 100 & $\begin{array}{l}\text { Cancer lesions in oral } \\
\text { lichen planus }\end{array}$ & $\begin{array}{l}2000 \mathrm{mg} / \text { day; } 7 \text { weeks, } \\
\text { combined with prednisone }\end{array}$ & Not efficacious but well tolerated & [293] \\
\hline 12 & Phase I/II trial & 29 & Multiple myeloma & $\begin{array}{l}2000-12,000 \mathrm{mg} / \text { day; } 12 \\
\text { weeks combined with } \\
\text { Bioperine }\end{array}$ & $\begin{array}{l}\text { Well tolerated, improved bioavailability and decrease in } \\
\qquad \mathrm{NF}-\kappa \mathrm{B}, \mathrm{COX} 2 \text { and STAT3 }\end{array}$ & [304] \\
\hline 13 & Phase II trial & 25 & $\begin{array}{l}\text { Advanced pancreatic } \\
\text { cancer }\end{array}$ & $8000 \mathrm{mg} /$ day; 2 months & $\begin{array}{l}\text { Well tolerated but absorption was limited and was effective } \\
\text { only in some patients }\end{array}$ & {$[305]$} \\
\hline 14 & Single blind, cross over & 26 & Multiple myeloma & 4000 gm/day; 6 months & $\begin{array}{l}\text { Urinary } N \text {-telopeptide of type I collagen and paraprotein } \\
\text { levels reduced }\end{array}$ & [306] \\
\hline
\end{tabular}


Table 1. Cont

\begin{tabular}{|c|c|c|c|c|c|c|}
\hline Serial & Study & $\begin{array}{c}\text { Number } \\
\text { of Patients }\end{array}$ & Health Condition & Dose & Outcome & Reference \\
\hline 15 & $\begin{array}{l}\text { Phase I, open-label, dose } \\
\text { escalation trial }\end{array}$ & 14 & $\begin{array}{l}\text { Advanced and } \\
\text { metastatic breast cancer }\end{array}$ & $\begin{array}{c}6000 \mathrm{mg} / \text { day; } 7 \text { days, } \\
\text { every } 3 \text { weeks, combined } \\
\text { with docetaxel }\end{array}$ & Well tolerated and efficacious & [307] \\
\hline 16 & Open-label, phase II trial & 17 & $\begin{array}{l}\text { Advanced pancreatic } \\
\text { cancer }\end{array}$ & $\begin{array}{c}8000 \text { mg/day; } 4 \text { weeks; } \\
\text { combined with } \\
\text { gemcitabine }\end{array}$ & Modest efficacy, therapy not a feasible & [308] \\
\hline 17 & $\begin{array}{l}\text { Randomized, double blind, } \\
\text { controlled }\end{array}$ & 85 & Prostate cancer & $\begin{array}{c}100 \mathrm{mg} / \text { day; } 6 \text { months, } \\
\text { combined with soy } \\
\text { isoflavones }\end{array}$ & Serum PSA content decreased & [309] \\
\hline 18 & Pilot study & 75 & Pre-cancerous lesions & $1000 \mathrm{mg} /$ day; 7 days & $\begin{array}{c}\text { MDA and } 8-O H d G \text { levels increased in saliva and serum } \\
\text { while Vitamin } \mathrm{C} \text { and E levels reduced }\end{array}$ & [294] \\
\hline 19 & Phase IIa trial & 44 & Colorectal cancer & $\begin{array}{l}2000-4000 \mathrm{mg} / \mathrm{day} ; \\
1 \text { month }\end{array}$ & Aberrant Crypt Foci formation reduced only in smokers & [310] \\
\hline 20 & Pilot study & 126 & Colorectal cancer & $1080 \mathrm{mg} /$ day; $10-30$ days & $\begin{array}{c}\text { Increased p53 expression, decrease in serum TNF- } \alpha \text { and } \\
\text { improved body weight }\end{array}$ & [233] \\
\hline 21 & Phase I/II & 21 & $\begin{array}{c}\text { Gemcitabine-resistant } \\
\text { pancreatic cancer }\end{array}$ & $8000 \mathrm{mg} /$ day & Well tolerated & [311] \\
\hline 22 & Pilot study & 39 & Head and neck cancer & 2 curcumin tablets & $\begin{array}{l}\text { IKK } \beta \text { kinase activity decreased which correlated with } \\
\text { IL- } 8 \text { decrease in saliva }\end{array}$ & {$[312]$} \\
\hline 23 & $\begin{array}{l}\text { Randomised, double blind, } \\
\text { placebo controlled }\end{array}$ & 20 & $\begin{array}{l}\text { Cancer lesions in oral } \\
\text { lichen planus }\end{array}$ & $6000 \mathrm{mg} /$ day; 14 days & Clinical symptoms reduced with no adverse effects & {$[295,313]$} \\
\hline 24 & $\begin{array}{l}\text { Randomised, double blind, } \\
\text { placebo controlled, cross over } \\
\text { followed by open label study }\end{array}$ & 36 & Multiple myeloma & $\begin{array}{l}4000 \mathrm{mg} / \text { day; } 3 \text { months } \\
\text { followed by } 8000 \mathrm{mg} / \text { day; } \\
3 \text { months }\end{array}$ & Slowed down disease progression & [314] \\
\hline 25 & Randomized, open label & 50 & $\begin{array}{l}\text { Chronic myeloid } \\
\text { leukaemia }\end{array}$ & $\begin{array}{l}15,000 \mathrm{mg} / \text { day; } 6 \text { weeks in } \\
\text { combination with imatinib }\end{array}$ & Enhanced decrease in nitric oxide levels & {$[315]$} \\
\hline
\end{tabular}




\section{(b) Colorectal Cancer}

Sharma et al., conducted two phase I trials in colorectal cancer patients who were refractory to conventional chemotherapeutics [298,300]. In the first study in 2001, curcuma extract, equivalent to 36-180 mg of curcumin, was given orally to 15 patients, daily for 4 months [298]. Dose-limiting toxicity was not observed and neither curcumin nor its metabolites were detected in blood or urine but were found in feces. The treatment maintained radiologically stable disease for 2-4 months in five patients. The study indicated safety but low oral bioavailability of curcumin. In a subsequent study in 2004, an escalating dose of curcuminoids comprising 450, 900, 1800, or $3600 \mathrm{mg}$ per day for 4 months was tested in 15 patients [300]. Curcumin and its metabolites were detected in plasma and urine. Overall, the drug was well-tolerated but three patients suffered from minor gastrointestinal adverse events. A minor increase of alkaline phosphate and lactate dehydrogenase was observed in the serum of four and three patients, respectively. Similar minor adverse effects in a few subjects were observed by Lao et al., in a prospective phase I trial conducted in 2006 [303]. In this study, 24 healthy volunteers were given escalating doses of 500,1000, 2000, 4000, 8000, 10,000 and 12,000 mg in a single dose and safety was assessed $72 \mathrm{~h}$ later. $30 \%$ of the subjects experienced diarrhea, headache, rash, and yellowish stools irrespective of the dose.

Garcea et al., investigated whether pharmacologically active levels of curcumin could be achieved in the colon and rectum of colorectal cancer patients [299]. After oral administration of 450, 1800, or $3600 \mathrm{mg}$ of curcumin every day for 7 days, traces of curcumin and its metabolites were found in normal mucosa, malignant colorectal tissues, and intestinal tissues. The observed decrease in malondialdehyde-DNA M1G-adduct and COX-2 in colorectal tissues suggested efficacy of the dosage. Even in combination therapy, wherein $480 \mathrm{mg}$ of curcumin was given with $20 \mathrm{mg}$ of quercetin thrice a day, the number and size of polyps in patients suffering from familial adenomatous polyposis was found to be reduced after 6 months of treatment [302]. In a non-randomized, open-label, phase IIa trial, 44 smokers with eight or more aberrant crypt foci (ACF), which are a precursor of colorectal polyps, were treated with 2000 or $4000 \mathrm{mg}$ of curcumin daily for 30 days [310]. Only the higher dose significantly reduced ACF formation, which was associated with a five-fold increase in post-treatment plasma curcumin/conjugate levels. However, the underlying mechanism is yet unclear. In another study, $360 \mathrm{mg}$ of curcumin was administered thrice a day for 10-30 days in colorectal cancer patients after diagnosis and before surgery [233]. Curcumin administration resulted in an increase in body weight, number of apoptotic cells, and p53 expression, while it decreased TNF- $\alpha$ level in serum. The study concluded that curcumin treatment can improve the general health of colorectal cancer patients, probably, but not necessarily, due to the increase in p53 expression.

\section{(c) Multiple Myeloma}

The chemopreventive potential of curcumin in monoclonal gammopathy of undetermined significance (MGUS), a high-risk condition for progression to multiple myeloma, was tested by Golombick et al., in a cross-over study design [306]. Out of 27 patients, 17 received $4000 \mathrm{mg}$ of curcumin for 3 months before cross-over to placebo. The rest received placebo first, followed by curcumin. The levels of paraprotein and urinary $\mathrm{N}$-telopeptide from type I collagen decreased in some 
patients. The same group reported beneficial effects of curcumin in MGUS in another randomized, double blind, placebo-controlled cross-over study [314]. A phase I/II trial by Vadhan-Raj et al., in 29 patients with asymptomatic, relapsed, or plateau phase multiple myeloma showed a decrease in expression of NF- $\mathrm{kB}, \mathrm{COX}-2$, and STAT3 in peripheral blood mononuclear cells and stable maintenance of disease [304]. The patients were given either oral dose of curcumin alone (2000, 4000, 6000, 8000, or $12,000 \mathrm{mg}$ /day) or in combination with $10 \mathrm{mg}$ of bioperine. 12 patients continued the treatment for 12 weeks, followed by combination treatment for five patients (one at a dose of 4000, two at $6000 \mathrm{mg}$, and two at $8000 \mathrm{mg}$ ) for 1 year. Further, well-controlled clinical trials with larger sample sizes are required to substantiate the efficacy of curcumin against multiple myeloma.

\section{(d) Pancreatic Cancer}

Dhillon et al., conducted a phase II clinical trial in 25 advanced pancreatic cancer patients [305]. An oral dose of $8000 \mathrm{mg}$ of curcumin was given every day until disease progression, with restaging performed every 2 months. Low, steady-state levels of curcumin and its conjugates were detected in the peripheral circulation for the first 4 weeks with a peak at $22-42 \mathrm{ng} / \mathrm{mL}$. In two patients, a biological effect was seen and in one the disease was maintained stably for 18 months. Remarkably, a significant but brief tumor regression was seen in one patient with a concomitant increase in serum cytokine levels. NF- $\mathrm{B}, \mathrm{COX}-2$, and STAT3 suppression in peripheral mononuclear cells was also observed in the patients. Although oral curcumin was found to be safe and well-tolerated, poor bioavailability still remains an issue, which partly explains the biologic activity observed only in some patients. In another open-label, phase II trial, a combination of curcumin and gemcitabine was tested in advanced pancreatic cancer patients [308]. Seventeen patients were administered $8000 \mathrm{mg}$ of curcumin orally every day for 4 weeks while $1000 \mathrm{mg} / \mathrm{m}^{3}$ of gemcitabine were given intravenously three times a week. In five patients, curcumin or the whole treatment was discontinued due to toxicity and one patient died suddenly. In the remaining 11 patients, a partial response was seen; four had stable disease while in six the tumor progressed. Tumor progression time was 1-12 months, with overall survival time of 1-24 months, indicating a modest efficacy of the combination therapy. Also, the authors concluded that $8000 \mathrm{mg} / \mathrm{day}$ of curcumin with gemcitabine was above the maximum tolerated dose. In a recent phase I/II trial by Kanai et al., a similar combination of gemcitabine and curcumin was used to treat gemcitabine-resistant pancreatic cancer in 21 patients [311]. In contrast, the combination of gemcitabine and curcumin $8000 \mathrm{mg} /$ day was found to be safe and well tolerated in this study. Studies in a larger cohort are required to validate the results.

\section{(e) Breast Cancer}

An open-label, phase I clinical trial was conducted by Bayet-Robert et al., to evaluate the feasibility and tolerability of curcumin in combination with docetaxel [307]. Fourteen patients with advanced or metastatic breast cancer were given $100 \mathrm{mg} / \mathrm{m}^{3}$ of docetaxel every 3 weeks on day 1 for six cycles, while an oral escalating dose of curcumin was given for seven consecutive days, starting from $500 \mathrm{mg} /$ day until a dose-limiting toxicity was observed. The authors reported that the maximum tolerable dose was $8000 \mathrm{mg}$ /day but they advocated $6000 \mathrm{mg} /$ day for 7 consecutive days every 3 weeks in combination with the standard docetaxel dose for treatment of breast cancer. 


\section{(f) Prostate Cancer}

Ide et al., conducted a randomized, double blind study, wherein the efficacy of a combination therapy of soy isoflavones and curcumin was evaluated [309]. Eighty five participants who underwent prostate biopsies because of increased PSA (prostate-specific antigen) levels but had negative prostate cancer findings were enrolled. Either a supplement containing $40 \mathrm{mg}$ of isoflavones and $100 \mathrm{mg}$ of curcumin or placebo was administered daily for six months. Serum PSA levels decreased in the combination therapy group. The authors suggested a possible synergistic role of curcumin with soy isoflavones in the suppression of PSA production. The anti-cancer activity of curcumin via inhibition of IKK $\beta$ kinase activity was examined in patients with head and neck squamous cell carcinoma (HNSCC) [312]. 13 patients with dental carries, 21 with HNSCC, and five healthy volunteers (total 39) were given two tablets, which they chewed for $5 \mathrm{~min}$. IKK $\beta$ kinase activity was suppressed in salivary cells while IL- 8 levels decreased in patients with dental carries, but the decrease in IL-8 levels was not significant in HNSCC patients. The authors suggested the use of IKK $\beta$ kinase as a biomarker for assessing the effect of curcumin in HNSCC.

\section{(g) Chronic Myeloid Leukemia}

Recently, in a randomized open label study, the efficacy and safety of curcumin was evaluated against chronic myeloid leukemia [315]. 25 participants were given $800 \mathrm{mg}$ of imatinib daily for 6 weeks while the rest were given a combination of $800 \mathrm{mg}$ of imatinib with $5000 \mathrm{mg}$ of curcumin thrice a day. Nitric oxide levels were found to decrease significantly in the combination therapy group, as compared to placebo and imatinib only group. The authors advocated the use of curcumin as an adjuvant to imatinib for the treatment of chronic myeloid leukemia.

\section{Conclusions}

A plethora of in vitro and in vivo research together with clinical trials conducted over the past few decades substantiate the potential of curcumin as an anti-cancer agent. At the molecular level, curcumin targets numerous pathways, highlighting its ability to inhibit carcinogenesis at multiple levels and thus, potentially circumventing the development of resistance. However, there is a paucity of data to explain the underlying mechanism of its activity. Clinical trials with curcumin indicate safety, tolerability, non-toxicity (even up to doses of $8000 \mathrm{mg} /$ day), and efficacy. These studies provide a solid foundation for more well-controlled studies in larger cohorts as well as open avenues for future drug development. However, curcumin activity is limited by its poor bioavailability and some possible adverse effects. The development of formulations of curcumin in the form of nanoparticles, liposomes, micelles or phospholipid complexes to enhance its bioavailability and efficacy are still in its early stages. Nonetheless, curcumin has established itself as a safe and promising molecule for the prevention and therapy of not only cancer but also other inflammation-driven diseases.

\section{Acknowledgments}

This work was supported by NUHS Bench-to- Bedside-To-Product grant to GS. Deanship of Scientific Research, College of Science Research Centre, King Saud University, Kingdom of Saudi 
Arabia is also acknowledged. GS also thanks King Saud University, Riyadh, Kingdom of Saudi Arabia, for the Visiting Professorship. APK was supported by grants from the Singapore Ministry of Education Tier 2 [MOE2012-T2-2-139], NUHS Bench-to-Bedside-To-Product [R-184-000-243-515] and Cancer Science Institute of Singapore, Experimental Therapeutics I Program [R-713-001-011-271].

\section{Author Contributions}

Gautam Sethi, Muthu K. Shanmugam, Grishma Rane, Madhu Mathi Kanchi conceived and designed the manuscript; Muthu K. Shanmugam, Grishma Rane and Madhu Mathi Kanchi wrote the manuscript; Frank Arfuso, Arunachalam Chinnathambi, M. E. Zayed, Sulaiman Ali Alharbi, Alan Prem Kumar critically analyzed the manuscript; Benny K. H. Tan, Gautam Sethi, Muthu K. Shanmugam proof read the manuscript.

\section{Abbreviation}

AP-1, activator protein 1; AAPK, Abscisic-acid-activated protein kinase; AHR, aryl hydrocarbon receptor; AR, androgen receptor; AK, adenylate kinase; ATPase, adenosine triphosphatases; Bad, Bcl2 associated death promoter protein; Bid, $\mathrm{BH} 3$ interacting-domain death agonist; Bcl2, B-cell lymphoma 2; Bcl-xL, B-cell lymphoma extra-large; Bax, Bcl-2-associated X protein; CTGF, connective tissue growth factor; $\mathrm{CXCR}$, chemokine receptor; $\mathrm{CXCL}$, chemokine ligand; $\mathrm{Ca} 2+\mathrm{PK}$, calcium/calmodulin dependent protein kinase; CREB-BP, CREB-binding protein; CCND1, Cyclin D1; COX-2, cyclooxygenase-2; c-myc, Myelocytomatosis cellular oncogene; DR, death receptor; DEF-40, Differentially Expressed In FDCP; EGFR, epidermal growth factor receptor; EGFR-K, Epidermal growth factor receptor-kinase; ERK, extracellular-signal-regulated kinases; ECM, extracellular matrix; ER- $\alpha$, estrogen receptor-alpha; EPCR, Endothelial protein C receptor; ELAM-1, endothelial-leukocyte adhesion molecule-1; EGF, epidermal growth factor; ERE, estrogen response element; EGR-1, early growth response; FAK, Focal Adhesion Kinase; vFLIP, viral FADD-like interleukin-1 $\beta$-converting enzyme (FLICE)/caspase-8-inhibitory protein; FGF, fibroblast growth factor; Fas R, Fas receptor/CD95; FPT, Farnesyl protein transferase; GST, glutathione-S-transferase Telomerase; GCL, Glutamate Cysteine Ligase; HGF, hepatocyte growth factor; HIF-1 $\alpha$, hypoxia-inducible factor $1 \alpha$; H2R, histamine H2 receptor; HER-2, human epidermal growth factor receptor 2; Hsp-70, Heat shock protein-70; ICAM-1, intracellular adhesion molecule 1; IL, interleukin; IGF-1, insulin-like growth factor; I $\mathrm{B}$, inhibitory $\kappa \mathrm{B}$; IKK, IкB kinase; IAP-1, inhibitor of apoptosis; IR, insulin receptor; ITR, Inositol triphosphate receptor; iNOS, inducible nitric oxide synthase; JAK, Janus kinase; LDLR, Low-Density Lipoprotein receptor; 5-LOX, 5-lipoxygenase; MMP, matrix metalloproteinase; MCP, monocyte chemoattractant protein; MIP, macrophage inflammatory protein; MDRP, multidrug resistant protein; MAPK, mitogen-activated protein kinase; NF- $\kappa \mathrm{B}$, nuclear factor $\kappa \mathrm{B}$; Nrf-2, Nuclear factor (erythroid-derived 2)-like 2; NGF, nerve growth factor; NSCLC, non-small cell lung cancer; NQO-1, NAD(P)H:quinone acceptor oxidoreductase 1; ODC, ornithine decarboxylase; PTK, protein tyrosine kinase; PKA, protein kinase A; PKB, protein kinase B/AKT; PhK, Phosphorylase kinase; PAK, p21 activated kinases; Pp60C-TK, pp60c-src tyrosine kinase; PDGF, platelet derived growth factor; $\mathrm{p} 53$, tumor suppressor gene; PPAR- $\gamma$, peroxisome proliferator associated receptor gamma; cPLA2, Secreted phospholipases A2; PI3K, Phosphoinositide-3-kinase; RCC, renal cell carcinoma; ROS, reactive oxygen species; Src-2, src-non receptor tyrosine kinase; 
STAT3, signal transducer and activator of transcription 3; SCC, squamous cell carcinoma; TNF, tumor necrosis factor; TF, tissue factor; TGF- $\beta 1$, transforming growth factor-beta; TMMP-3, truncated matrix metalloprotease-3; TAM, tumor-associated macrophage; uPA, urokinase plasminogen activator; VEGF, vascular endothelial growth factor; VCAM-1, vascular cell adhesion molecule 1; WT-1, Wilms tumor-1; XIAP, X-linked inhibitor of apoptosis.

\section{Conflicts of Interest}

The authors declare no conflict of interest.

\section{References}

1. Ammon, H.P.; Wahl, M.A. Pharmacology of Curcuma longa. Planta Med. 1991, 57, 1-7.

2. Chan, M.M.; Adapala, N.S.; Fong, D. Curcumin overcomes the inhibitory effect of nitric oxide on Leishmania. Parasitol Res. 2005, 96, 49-56.

3. Sreejayan; Rao, M.N. Nitric oxide scavenging by curcuminoids. J. Pharm. Pharmacol. 1997, 49, $105-107$.

4. Brouet, I.; Ohshima, H. Curcumin, an anti-tumour promoter and anti-inflammatory agent, inhibits induction of nitric oxide synthase in activated macrophages. Biochem. Biophys. Res. Commun. 1995, 206, 533-540.

5. Dikshit, M.; Rastogi, L.; Shukla, R.; Srimal, R.C. Prevention of ischaemia-induced biochemical changes by curcumin \& quinidine in the cat heart. Indian J. Med. Res. 1995, 101, 31-35.

6. Kiso, Y.; Suzuki, Y.; Watanabe, N.; Oshima, Y.; Hikino, H. Antihepatotoxic principles of Curcuma longa rhizomes. Planta Med. 1983, 49, 185-187.

7. Venkatesan, N. Curcumin attenuation of acute adriamycin myocardial toxicity in rats. $B r . J$. Pharmacol. 1998, 124, 425-427.

8. Srivastava, R.; Dikshit, M.; Srimal, R.C.; Dhawan, B.N. Anti-thrombotic effect of curcumin. Thromb. Res. 1985, 40, 413-417.

9. Deodhar, S.D.; Sethi, R.; Srimal, R.C. Preliminary study on antirheumatic activity of curcumin (diferuloyl methane). Indian J. Med. Res. 1980, 71, 632-634.

10. Chen, A.; Xu, J.; Johnson, A.C. Curcumin inhibits human colon cancer cell growth by suppressing gene expression of epidermal growth factor receptor through reducing the activity of the transcription factor Egr-1. Oncogene 2006, 25, 278-287.

11. Chen, J.; Tang, X.Q.; Zhi, J.L.; Cui, Y.; Yu, H.M.; Tang, E.H.; Sun, S.N.; Feng, J.Q.; Chen, P.X. Curcumin protects PC12 cells against 1-methyl-4-phenylpyridinium ion-induced apoptosis by bcl-2-mitochondria-ROS-iNOS pathway. Apoptosis 2006, 11, 943-953.

12. Divya, C.S.; Pillai, M.R. Antitumor action of curcumin in human papillomavirus associated cells involves downregulation of viral oncogenes, prevention of NFkB and AP-1 translocation, and modulation of apoptosis. Mol. Carcinog. 2006, 45, 320-332.

13. Shishodia, S.; Chaturvedi, M.M.; Aggarwal, B.B. Role of curcumin in cancer therapy. Curr. Probl. Cancer 2007, 31, 243-305.

14. Shanmugam, M.K.; Kannaiyan, R.; Sethi, G. Targeting cell signaling and apoptotic pathways by dietary agents: Role in the prevention and treatment of cancer. Nutr. Cancer 2011, 63, 161-173. 
15. Aggarwal, B.B.; Sundaram, C.; Malani, N.; Ichikawa, H. Curcumin: The Indian solid gold. Adv. Exp. Med. Biol. 2007, 595, 1-75.

16. Anand, P.; Sundaram, C.; Jhurani, S.; Kunnumakkara, A.B.; Aggarwal, B.B. Curcumin and cancer: An "old-age" disease with an "age-old" solution. Cancer Lett. 2008, 267, 133-164.

17. Aggarwal, B.B.; Gehlot, P. Inflammation and cancer: How friendly is the relationship for cancer patients? Curr. Opin. Pharmacol. 2009, 9, 351-369.

18. Aggarwal, B.B.; Shishodia, S.; Sandur, S.K.; Pandey, M.K.; Sethi, G. Inflammation and cancer: How hot is the link? Biochem. Pharmacol. 2006, 72, 1605-1621.

19. Gupta, S.C.; Prasad, S.; Kim, J.H.; Patchva, S.; Webb, L.J.; Priyadarsini, I.K.; Aggarwal, B.B. Multitargeting by curcumin as revealed by molecular interaction studies. Nat. Prod. Rep. 2011, 28, 1937-1955.

20. Sethi, G.; Shanmugam, M.K.; Ramachandran, L.; Kumar, A.P.; Tergaonkar, V. Multifaceted link between cancer and inflammation. Biosci. Rep. 2012, 32, 1-15.

21. Balkwill, F.; Mantovani, A. Inflammation and cancer: Back to Virchow? Lancet 2001, 357, 539-545.

22. Sethi, G.; Tergaonkar, V. Potential pharmacological control of the NF-kappaB pathway. Trends Pharmacol. Sci. 2009, 30, 313-321.

23. Hanahan, D.; Weinberg, R.A. The hallmarks of cancer. Cell 2000, 100, 57-70.

24. Hanahan, D.; Weinberg, R.A. Hallmarks of cancer: The next generation. Cell 2011, 144, 646-674.

25. Dibb, N.J.; Dilworth, S.M.; Mol, C.D. Switching on kinases: Oncogenic activation of BRAF and the PDGFR family. Nat. Rev. Cancer 2004, 4, 718-727.

26. Manning, B.D.; Cantley, L.C. AKT/PKB signaling: Navigating downstream. Cell 2007, 129, 1261-1274.

27. Lemmon, M.A.; Schlessinger, J. Cell signaling by receptor tyrosine kinases. Cell 2010, 141, 1117-1134.

28. Siveen, K.S.; Sikka, S.; Surana, R.; Dai, X.; Zhang, J.; Kumar, A.P.; Tan, B.K.; Sethi, G.; Bishayee, A. Targeting the STAT3 signaling pathway in cancer: Role of synthetic and natural inhibitors. Biochim. Biophys. Acta 2014, 1845, 136-154.

29. Heger, M.; van Golen, R.F.; Broekgaarden, M.; Michel, M.C. The molecular basis for the pharmacokinetics and pharmacodynamics of curcumin and its metabolites in relation to cancer. Pharmacol. Rev. 2014, 66, 222-307.

30. Eferl, R.; Wagner, E.F. AP-1: A double-edged sword in tumorigenesis. Nat. Rev. Cancer 2003, 3, 859-868.

31. Roux, P.P.; Blenis, J. ERK and p38 MAPK-activated protein kinases: A family of protein kinases with diverse biological functions. Microbiol. Mol. Biol. Rev. 2004, 68, 320-344.

32. Lopez-Bergami, P.; Lau, E.; Ronai, Z. Emerging roles of ATF2 and the dynamic AP1 network in cancer. Nat. Rev. Cancer 2010, 10, 65-76.

33. Arnott, C.H.; Scott, K.A.; Moore, R.J.; Hewer, A.; Phillips, D.H.; Parker, P.; Balkwill, F.R.; Owens, D.M. Tumour necrosis factor-alpha mediates tumour promotion via a PKC alpha- and AP-1-dependent pathway. Oncogene 2002, 21, 4728-4738.

34. Kolch, W.; Pitt, A. Functional proteomics to dissect tyrosine kinase signalling pathways in cancer. Nat. Rev. Cancer 2010, 10, 618-629. 
35. Peeper, D.S.; Bernards, R. Communication between the extracellular environment, cytoplasmic signalling cascades and the nuclear cell-cycle machinery. FEBS Lett. 1997, 410, 11-16.

36. Peeper, D.S.; Upton, T.M.; Ladha, M.H.; Neuman, E.; Zalvide, J.; Bernards, R.; DeCaprio, J.A.; Ewen, M.E. Ras signalling linked to the cell-cycle machinery by the retinoblastoma protein. Nature 1997, 386, 177-181.

37. Karin, M.; Liu, Z.; Zandi, E. AP-1 function and regulation. Curr. Opin. Cell Biol. 1997, 9, 240-246.

38. Dhandapani, K.M.; Mahesh, V.B.; Brann, D.W. Curcumin suppresses growth and chemoresistance of human glioblastoma cells via AP-1 and NFkappaB transcription factors. J. Neurochem. 2007, 102, 522-538.

39. Woo, M.S.; Jung, S.H.; Kim, S.Y.; Hyun, J.W.; Ko, K.H.; Kim, W.K.; Kim, H.S. Curcumin suppresses phorbol ester-induced matrix metalloproteinase-9 expression by inhibiting the PKC to MAPK signaling pathways in human astroglioma cells. Biochem. Biophys. Res. Commun. 2005, 335, 1017-1025.

40. Dyer, J.L.; Khan, S.Z.; Bilmen, J.G.; Hawtin, S.R.; Wheatley, M.; Javed, M.U.; Michelangeli, F. Curcumin: A new cell-permeant inhibitor of the inositol 1,4,5-trisphosphate receptor. Cell Calcium. 2002, 31, 45-52.

41. Wang, X.; Wang, Q.; Ives, K.L.; Evers, B.M. Curcumin inhibits neurotensin-mediated interleukin-8 production and migration of HCT116 human colon cancer cells. Clin. Cancer Res. 2006, 12, 5346-5355.

42. Chen, Y.R.; Tan, T.H. Inhibition of the c-Jun N-terminal kinase (JNK) signaling pathway by curcumin. Oncogene 1998, 17, 173-178.

43. Polytarchou, C.; Hatziapostolou, M.; Papadimitriou, E. Hydrogen peroxide stimulates proliferation and migration of human prostate cancer cells through activation of activator protein-1 and up-regulation of the heparin affin regulatory peptide gene. J. Biol. Chem. 2005, 280, 40428-40435.

44. Prusty, B.K.; Das, B.C. Constitutive activation of transcription factor AP-1 in cervical cancer and suppression of human papillomavirus (HPV) transcription and AP-1 activity in HeLa cells by curcumin. Int. J. Cancer 2005, 113, 951-960.

45. Garg, R.; Ingle, A.; Maru, G. Dietary turmeric modulates DMBA-induced p21ras, MAP kinases and AP-1/NF-kappaB pathway to alter cellular responses during hamster buccal pouch carcinogenesis. Toxicol. Appl. Pharmacol. 2008, 232, 428-439.

46. Seol, D.W.; Chen, Q.; Zarnegar, R. Transcriptional activation of the hepatocyte growth factor receptor (c-met) gene by its ligand (hepatocyte growth factor) is mediated through AP-1. Oncogene 2000, 19, 1132-1137.

47. Sethi, G.; Sung, B.; Aggarwal, B.B. Nuclear factor-kappaB activation: From bench to bedside. Exp. Biol. Med. (Maywood) 2008, 233, 21-31.

48. Low, K.C.; Tergaonkar, V. Telomerase: Central regulator of all of the hallmarks of cancer. Trends Biochem. Sci. 2013, 38, 426-434.

49. Ghosh, A.; Saginc, G.; Leow, S.C.; Khattar, E.; Shin, E.M.; Yan, T.D.; Wong, M.; Zhang, Z.; Li, G.; Sung, W.K.; et al. Telomerase directly regulates NF-kappaB-dependent transcription. Nat. Cell Biol. 2012, 14, 1270-1281. 
50. Chaturvedi, M.M.; Sung, B.; Yadav, V.R.; Kannappan, R.; Aggarwal, B.B. NF-kappaB addiction and its role in cancer: "One size does not fit all”. Oncogene 2011, 30, 1615-1630.

51. Li, F.; Sethi, G. Targeting transcription factor NF-kappaB to overcome chemoresistance and radioresistance in cancer therapy. Biochim. Biophys. Acta 2010, 1805, 167-180.

52. Ahn, K.S.; Sethi, G.; Aggarwal, B.B. Nuclear factor-kappa B: From clone to clinic. Curr. Mol. Med. 2007, 7, 619-637.

53. Cildir, G.; Akincilar, S.C.; Tergaonkar, V. Chronic adipose tissue inflammation: All immune cells on the stage. Trends Mol. Med. 2013, 19, 487-500.

54. Shen, H.M.; Tergaonkar, V. NFkappaB signaling in carcinogenesis and as a potential molecular target for cancer therapy. Apoptosis 2009, 14, 348-363.

55. Wong, E.T.; Tergaonkar, V. Roles of NF-kappaB in health and disease: Mechanisms and therapeutic potential. Clin. Sci. (Lond.) 2009, 116, 451-465.

56. Chew, J.; Biswas, S.; Shreeram, S.; Humaidi, M.; Wong, E.T.; Dhillion, M.K.; Teo, H.; Hazra, A.; Fang, C.C.; Lopez-Collazo, E.; et al. WIP1 phosphatase is a negative regulator of NF-kappaB signalling. Nat. Cell Biol. 2009, 11, 659-666.

57. Shishodia, S.; Singh, T.; Chaturvedi, M.M. Modulation of transcription factors by curcumin. Adv. Exp. Med. Biol. 2007, 595, 127-148.

58. Kuttan, R.; Bhanumathy, P.; Nirmala, K.; George, M.C. Potential anticancer activity of turmeric (Curcuma longa). Cancer Lett. 1985, 29, 197-202.

59. Kuttan, R.; Sudheeran, P.C.; Josph, C.D. Turmeric and curcumin as topical agents in cancer therapy. Tumori 1987, 73, 29-31.

60. Singh, S.; Aggarwal, B.B. Activation of transcription factor NF-kappa B is suppressed by curcumin (diferuloylmethane) [corrected]. J. Biol. Chem. 1995, 270, 24995-25000.

61. Prasad, S.; Gupta, S.C.; Tyagi, A.K.; Aggarwal, B.B. Curcumin, a component of golden spice: From bedside to bench and back. Biotechnol. Adv. 2014, 32, 1053-1064.

62. Jobin, C.; Bradham, C.A.; Russo, M.P.; Juma, B.; Narula, A.S.; Brenner, D.A.; Sartor, R.B. Curcumin blocks cytokine-mediated NF-kappa B activation and proinflammatory gene expression by inhibiting inhibitory factor I-kappa B kinase activity. J. Immunol. 1999, 163, 3474-3483.

63. Plummer, S.M.; Holloway, K.A.; Manson, M.M.; Munks, R.J.; Kaptein, A.; Farrow, S.; Howells, L. Inhibition of cyclo-oxygenase 2 expression in colon cells by the chemopreventive agent curcumin involves inhibition of NF-kappaB activation via the NIK/IKK signalling complex. Oncogene 1999, 18, 6013-6020.

64. Shishodia, S.; Potdar, P.; Gairola, C.G.; Aggarwal, B.B. Curcumin (diferuloylmethane) down-regulates cigarette smoke-induced NF-kappaB activation through inhibition of IkappaBalpha kinase in human lung epithelial cells: Correlation with suppression of COX-2, MMP-9 and cyclin D1. Carcinogenesis 2003, 24, 1269-1279.

65. Shishodia, S.; Amin, H.M.; Lai, R.; Aggarwal, B.B. Curcumin (diferuloylmethane) inhibits constitutive NF-kappaB activation, induces G1/S arrest, suppresses proliferation, and induces apoptosis in mantle cell lymphoma. Biochem. Pharmacol. 2005, 70, 700-713. 
66. Aggarwal, B.B.; Shishodia, S.; Takada, Y.; Banerjee, S.; Newman, R.A.; Bueso-Ramos, C.E.; Price, J.E. Curcumin suppresses the paclitaxel-induced nuclear factor-kappaB pathway in breast cancer cells and inhibits lung metastasis of human breast cancer in nude mice. Clin. Cancer Res. 2005, 11, 7490-7498.

67. Philip, S.; Kundu, G.C. Osteopontin induces nuclear factor kappa B-mediated promatrix metalloproteinase-2 activation through I kappa B alpha /IKK signaling pathways, and curcumin (diferulolylmethane) down-regulates these pathways. J. Biol. Chem. 2003, 278, 14487-14497.

68. Zheng, M.; Ekmekcioglu, S.; Walch, E.T.; Tang, C.H.; Grimm, E.A. Inhibition of nuclear factor-kappaB and nitric oxide by curcumin induces $\mathrm{G} 2 / \mathrm{M}$ cell cycle arrest and apoptosis in human melanoma cells. Melanoma Res. 2004, 14, 165-171.

69. Wang, Z.; Zhang, Y.; Banerjee, S.; Li, Y.; Sarkar, F.H. Notch-1 down-regulation by curcumin is associated with the inhibition of cell growth and the induction of apoptosis in pancreatic cancer cells. Cancer 2006, 106, 2503-2513.

70. Dikshit, P.; Goswami, A.; Mishra, A.; Chatterjee, M.; Jana, N.R. Curcumin induces stress response, neurite outgrowth and prevent NF-kappaB activation by inhibiting the proteasome function. Neurotox Res. 2006, 9, 29-37.

71. Milacic, V.; Banerjee, S.; Landis-Piwowar, K.R.; Sarkar, F.H.; Majumdar, A.P.; Dou, Q.P. Curcumin inhibits the proteasome activity in human colon cancer cells in vitro and in vivo. Cancer Res. 2008, 68, 7283-7292.

72. Bobrovnikova-Marjon, E.V.; Marjon, P.L.; Barbash, O.; Vander Jagt, D.L.; Abcouwer, S.F. Expression of angiogenic factors vascular endothelial growth factor and interleukin-8/CXCL8 is highly responsive to ambient glutamine availability: Role of nuclear factor-kappaB and activating protein-1. Cancer Res. 2004, 64, 4858-4869.

73. Kunnumakkara, A.B.; Anand, P.; Aggarwal, B.B. Curcumin inhibits proliferation, invasion, angiogenesis and metastasis of different cancers through interaction with multiple cell signaling proteins. Cancer Lett. 2008, 269, 199-225.

74. Yodkeeree, S.; Ampasavate, C.; Sung, B.; Aggarwal, B.B.; Limtrakul, P. Demethoxycurcumin suppresses migration and invasion of MDA-MB-231 human breast cancer cell line. Eur. J. Pharmacol. 2010, 627, 8-15.

75. Zong, H.; Wang, F.; Fan, Q.X.; Wang, L.X. Curcumin inhibits metastatic progression of breast cancer cell through suppression of urokinase-type plasminogen activator by NF-kappa B signaling pathways. Mol. Biol. Rep. 2012, 39, 4803-4808.

76. Sen, G.S.; Mohanty, S.; Hossain, D.M.; Bhattacharyya, S.; Banerjee, S.; Chakraborty, J.; Saha, S.; Ray, P.; Bhattacharjee, P.; Mandal, D.; et al. Curcumin enhances the efficacy of chemotherapy by tailoring p65NFkappaB-p300 cross-talk in favor of p53-p300 in breast cancer. J. Biol. Chem. 2011, 286, 42232-42247.

77. Kim, S.R.; Park, H.J.; Bae, Y.H.; Ahn, S.C.; Wee, H.J.; Yun, I.; Jang, H.O.; Bae, M.K.; Bae, S.K. Curcumin down-regulates visfatin expression and inhibits breast cancer cell invasion. Endocrinology 2012, 153, 554-563.

78. Royt, M.; Mukherjee, S.; Sarkar, R.; Biswas, J. Curcumin sensitizes chemotherapeutic drugs via modulation of PKC, telomerase, NF-kappaB and HDAC in breast cancer. Ther. Deliv. 2011, 2, 1275-1293. 
79. Huang, T.; Chen, Z.; Fang, L. Curcumin inhibits LPS-induced EMT through downregulation of NF-kappaB-Snail signaling in breast cancer cells. Oncol. Rep. 2013, 29, 117-124.

80. Jiang, M.; Huang, O.; Zhang, X.; Xie, Z.; Shen, A.; Liu, H.; Geng, M.; Shen, K. Curcumin induces cell death and restores tamoxifen sensitivity in the antiestrogen-resistant breast cancer cell lines MCF-7/LCC2 and MCF-7/LCC9. Molecules 2013, 18, 701-720.

81. Vinod, B.S.; Antony, J.; Nair, H.H.; Puliyappadamba, V.T.; Saikia, M.; Narayanan, S.S.; Bevin, A.; Anto, R.J. Mechanistic evaluation of the signaling events regulating curcumin-mediated chemosensitization of breast cancer cells to 5-fluorouracil. Cell Death Dis. 2013, 4, e505.

82. Sandur, S.K.; Deorukhkar, A.; Pandey, M.K.; Pabon, A.M.; Shentu, S.; Guha, S.; Aggarwal, B.B.; Krishnan, S. Curcumin modulates the radiosensitivity of colorectal cancer cells by suppressing constitutive and inducible NF-kappaB activity. Int. J. Radiat. Oncol. Biol. Phys. 2009, 75, 534-542.

83. Shakibaei, M.; Mobasheri, A.; Lueders, C.; Busch, F.; Shayan, P.; Goel, A. Curcumin enhances the effect of chemotherapy against colorectal cancer cells by inhibition of NF-kappaB and Src protein kinase signaling pathways. PLoS One 2013, 8, e57218.

84. Shin, H.K.; Kim, J.; Lee, E.J.; Kim, S.H. Inhibitory effect of curcumin on motility of human oral squamous carcinoma YD-10B cells via suppression of ERK and NF-kappaB activations. Phytother. Res. PTR 2010, 24, 577-582.

85. Kamat, A.M.; Tharakan, S.T.; Sung, B.; Aggarwal, B.B. Curcumin potentiates the antitumor effects of Bacillus Calmette-Guerin against bladder cancer through the downregulation of NF-kappaB and upregulation of TRAIL receptors. Cancer Res. 2009, 69, 8958-8966.

86. Watanabe, F.T.; Chade, D.C.; Reis, S.T.; Piantino, C.; Dall' Oglio, M.F.; Srougi, M.; Leite, K.R. Curcumin, but not Prima-1, decreased tumor cell proliferation in the syngeneic murine orthotopic bladder tumor model. Clinics (Sao Paulo) 2011, 66, 2121-2124.

87. Zhang, C.; Li, B.; Zhang, X.; Hazarika, P.; Aggarwal, B.B.; Duvic, M. Curcumin selectively induces apoptosis in cutaneous T-cell lymphoma cell lines and patients' PBMCs: Potential role for STAT-3 and NF-kappaB signaling. J. Investig. Dermatol. 2010, 130, 2110-2119.

88. Khan, M.A.; Gahlot, S.; Majumdar, S. Oxidative stress induced by curcumin promotes the death of cutaneous T-cell lymphoma (HuT-78) by disrupting the function of several molecular targets. Mol. Cancer Ther. 2012, 11, 1873-1883.

89. Jutooru, I.; Chadalapaka, G.; Lei, P.; Safe, S. Inhibition of NFkappaB and pancreatic cancer cell and tumor growth by curcumin is dependent on specificity protein down-regulation. J. Biol. Chem. 2010, 285, 25332-25344.

90. Duarte, V.M.; Han, E.; Veena, M.S.; Salvado, A.; Suh, J.D.; Liang, L.J.; Faull, K.F.; Srivatsan, E.S.; Wang, M.B. Curcumin enhances the effect of cisplatin in suppression of head and neck squamous cell carcinoma via inhibition of IKKbeta protein of the NFkappaB pathway. Mol. Cancer Ther. 2010, 9, 2665-2675.

91. Vander Broek, R.; Snow, G.E.; Chen, Z.; van Waes, C. Chemoprevention of head and neck squamous cell carcinoma through inhibition of NF-kappaB signaling. Oral Oncol. 2014, 50, 930-941. 
92. Sun, Z.J.; Chen, G.; Zhang, W.; Hu, X.; Liu, Y.; Zhou, Q.; Zhu, L.X.; Zhao, Y.F. Curcumin dually inhibits both mammalian target of rapamycin and nuclear factor-kappaB pathways through a crossed phosphatidylinositol 3-kinase/Akt/IkappaB kinase complex signaling axis in adenoid cystic carcinoma. Mol. Pharmacol. 2011, 79, 106-118.

93. Zanotto-Filho, A.; Braganhol, E.; Schroder, R.; de Souza, L.H.; Dalmolin, R.J.; Pasquali, M.A.; Gelain, D.P.; Battastini, A.M.; Moreira, J.C. NFkappaB inhibitors induce cell death in glioblastomas. Biochem. Pharmacol. 2011, 81, 412-424.

94. Zanotto-Filho, A.; Braganhol, E.; Edelweiss, M.I.; Behr, G.A.; Zanin, R.; Schroder, R.; Battastini, A.M.; Simoes-Pires, A.; Moreira, J.C. The curry spice curcumin selectively inhibits cancer cells growth in vitro and in preclinical model of glioblastoma. J. Nutr. Biochem. 2012, 23, 591-601.

95. Liao, S.; Xia, J.; Chen, Z.; Zhang, S.; Ahmad, A.; Miele, L.; Sarkar, F.H.; Wang, Z. Inhibitory effect of curcumin on oral carcinoma CAL-27 cells via suppression of Notch-1 and NF-kappaB signaling pathways. J. Cell Biochem. 2011, 112, 1055-1065.

96. Prakobwong, S.; Gupta, S.C.; Kim, J.H.; Sung, B.; Pinlaor, P.; Hiraku, Y.; Wongkham, S.; Sripa, B.; Pinlaor, S.; Aggarwal, B.B. Curcumin suppresses proliferation and induces apoptosis in human biliary cancer cells through modulation of multiple cell signaling pathways. Carcinogenesis 2011, 32, 1372-1380.

97. Spiller, S.E.; Logsdon, N.J.; Deckard, L.A.; Sontheimer, H. Inhibition of nuclear factor kappa-B signaling reduces growth in medulloblastoma in vivo. BMC Cancer 2011, 11, 136.

98. Yu, L.L.; Wu, J.G.; Dai, N.; Yu, H.G.; Si, J.M. Curcumin reverses chemoresistance of human gastric cancer cells by downregulating the NF-kappaB transcription factor. Oncol. Rep. 2011, 26, 1197-1203.

99. Das, L.; Vinayak, M. Anti-carcinogenic action of curcumin by activation of antioxidant defence system and inhibition of NF-kappaB signalling in lymphoma-bearing mice. Biosci. Rep. 2012, 32, $161-170$.

100. Qiao, Q.; Jiang, Y.; Li, G. Curcumin improves the antitumor effect of X-ray irradiation by blocking the NF-kappaB pathway: An in vitro study of lymphoma. Anticancer Drugs 2012, 23, 597-605.

101. Tu, S.P.; Jin, H.; Shi, J.D.; Zhu, L.M.; Suo, Y.; Lu, G.; Liu, A.; Wang, T.C.; Yang, C.S. Curcumin induces the differentiation of myeloid-derived suppressor cells and inhibits their interaction with cancer cells and related tumor growth. Cancer Prev. Res. 2012, 5, 205-215.

102. Chen, S.S.; Michael, A.; Butler-Manuel, S.A. Advances in the treatment of ovarian cancer: A potential role of antiinflammatory phytochemicals. Discov. Med. 2012, 13, 7-17.

103. Kliem, C.; Merling, A.; Giaisi, M.; Kohler, R.; Krammer, P.H.; Li-Weber, M. Curcumin suppresses $\mathrm{T}$ cell activation by blocking $\mathrm{Ca}^{2+}$ mobilization and nuclear factor of activated $\mathrm{T}$ cells (NFAT) activation. J. Biol. Chem. 2012, 287, 10200-10209.

104. Berger, F.; Buchsler, I.; Munz, B. The effect of the NF-kappa B inhibitors curcumin and lactacystin on myogenic differentiation of rhabdomyosarcoma cells. Differentiation 2012, 83, 271-281.

105. Orr, W.S.; Denbo, J.W.; Saab, K.R.; Ng, C.Y.; Wu, J.; Li, K.; Garner, J.M.; Morton, C.L.; Du, Z.; Pfeffer, L.M.; et al. Curcumin potentiates rhabdomyosarcoma radiosensitivity by suppressing NF-kappaB activity. PLoS One 2013, 8, e51309. 
106. Rawat, N.; Alhamdani, A.; McAdam, E.; Cronin, J.; Eltahir, Z.; Lewis, P.; Griffiths, P.; Baxter, J.N.; Jenkins, G.J. Curcumin abrogates bile-induced NF-kappaB activity and DNA damage in vitro and suppresses NF-kappaB activity whilst promoting apoptosis in vivo, suggesting chemopreventative potential in Barrett's oesophagus. Clin. Transl. Oncol. 2012, 14, 302-311.

107. Almanaa, T.N.; Geusz, M.E.; Jamasbi, R.J. Effects of curcumin on stem-like cells in human esophageal squamous carcinoma cell lines. BMC Complement. Altern. Med. 2012, 12, 195.

108. Tian, F.; Fan, T.; Zhang, Y.; Jiang, Y.; Zhang, X. Curcumin potentiates the antitumor effects of 5 -FU in treatment of esophageal squamous carcinoma cells through downregulating the activation of NF-kappaB signaling pathway in vitro and in vivo. Acta Biochim. Biophys. Sin. (Shanghai) 2012, 44, 847-855.

109. Tian, F.; Zhang, C.; Tian, W.; Jiang, Y.; Zhang, X. Comparison of the effect of p65 siRNA and curcumin in promoting apoptosis in esophageal squamous cell carcinoma cells and in nude mice. Oncol. Rep. 2012, 28, 232-240.

110. Oiso, S.; Ikeda, R.; Nakamura, K.; Takeda, Y.; Akiyama, S.; Kariyazono, H. Involvement of NF-kappaB activation in the cisplatin resistance of human epidermoid carcinoma KCP-4 cells. Oncol. Rep. 2012, 28, 27-32.

111. Killian, P.H.; Kronski, E.; Michalik, K.M.; Barbieri, O.; Astigiano, S.; Sommerhoff, C.P.; Pfeffer, U.; Nerlich, A.G.; Bachmeier, B.E. Curcumin inhibits prostate cancer metastasis in vivo by targeting the inflammatory cytokines CXCL1 and -2. Carcinogenesis 2012, 33, 2507-2519.

112. Guo, H.; Xu, Y.M.; Ye, Z.Q.; Yu, J.H.; Hu, X.Y. Curcumin induces cell cycle arrest and apoptosis of prostate cancer cells by regulating the expression of IkappaBalpha, c-Jun and androgen receptor. Pharmazie 2013, 68, 431-434.

113. Hong, J.H.; Ahn, K.S.; Bae, E.; Jeon, S.S.; Choi, H.Y. The effects of curcumin on the invasiveness of prostate cancer in vitro and in vivo. Prostate Cancer Prostatic Dis. 2006, 9, 147-152.

114. Qiao, Q.; Jiang, Y.; Li, G. Curcumin enhances the response of non-Hodgkin's lymphoma cells to ionizing radiation through further induction of cell cycle arrest at the G2/M phase and inhibition of mTOR phosphorylation. Oncol. Rep. 2013, 29, 380-386.

115. Kewitz, S.; Volkmer, I.; Staege, M.S. Curcuma Contra Cancer? Curcumin and Hodgkin's Lymphoma. Cancer Growth Metastasis 2013, 6, 35-52.

116. Qiao, Q.; Jiang, Y.; Li, G. Inhibition of the PI3K/AKT-NF-kappaB pathway with curcumin enhanced radiation-induced apoptosis in human Burkitt's lymphoma. J. Pharmacol. Sci. 2013, 121, 247-256.

117. Hong, J.M.; Park, C.S.; Nam-Goong, I.S.; Kim, Y.S.; Lee, J.C.; Han, M.W.; Choi, J.I.; Kim, Y.I.; Kim, E.S. Curcumin Enhances Docetaxel-Induced Apoptosis of 8505C Anaplastic Thyroid Carcinoma Cells. Endocrinol. Metab. (Seoul) 2014, 29, 54-61.

118. Mangelsdorf, D.J.; Thummel, C.; Beato, M.; Herrlich, P.; Schutz, G.; Umesono, K.; Blumberg, B.; Kastner, P.; Mark, M.; Chambon, P.; et al. The nuclear receptor superfamily: The second decade. Cell 1995, 83, 835-839.

119. Sarraf, P.; Mueller, E.; Jones, D.; King, F.J.; DeAngelo, D.J.; Partridge, J.B.; Holden, S.A.; Chen, L.B.; Singer, S.; Fletcher, C.; et al. Differentiation and reversal of malignant changes in colon cancer through PPARgamma. Nat. Med. 1998, 4, 1046-1052. 
120. Gee, V.M.; Wong, F.S.; Ramachandran, L.; Sethi, G.; Kumar, A.P.; Yap, C.W. Identification of novel peroxisome proliferator-activated receptor-gamma (PPARgamma) agonists using molecular modeling method. J. Comput. Aided Mol. Des. 2014, 28, 1143-1151.

121. Ramachandran, L.; Manu, K.A.; Shanmugam, M.K.; Li, F.; Siveen, K.S.; Vali, S.; Kapoor, S.; Abbasi, T.; Surana, R.; Smoot, D.T.; et al. Isorhamnetin inhibits proliferation and invasion and induces apoptosis through the modulation of peroxisome proliferator-activated receptor gamma activation pathway in gastric cancer. J. Biol. Chem. 2012, 287, 38028-38040.

122. Sikka, S.; Chen, L.; Sethi, G.; Kumar, A.P. Targeting PPARgamma Signaling Cascade for the Prevention and Treatment of Prostate Cancer. PPAR Res. 2012, 2012, 968040.

123. Chen, A.; Xu, J. Activation of PPAR \{gamma\} by curcumin inhibits Moser cell growth and mediates suppression of gene expression of cyclin D1 and EGFR. Am. J. Physiol. Gastrointest Liver Physiol. 2005, 288, G447-G456.

124. Prakobwong, S.; Khoontawad, J.; Yongvanit, P.; Pairojkul, C.; Hiraku, Y.; Sithithaworn, P.; Pinlaor, P.; Aggarwal, B.B.; Pinlaor, S. Curcumin decreases cholangiocarcinogenesis in hamsters by suppressing inflammation-mediated molecular events related to multistep carcinogenesis. Int. J. Cancer 2011, 129, 88-100.

125. Tsuiji, K.; Takeda, T.; Li, B.; Wakabayashi, A.; Kondo, A.; Kimura, T.; Yaegashi, N. Inhibitory effect of curcumin on uterine leiomyoma cell proliferation. Gynecol. Endocrinol. 2011, 27, $512-517$.

126. Subramaniam, A.; Shanmugam, M.K.; Perumal, E.; Li, F.; Nachiyappan, A.; Dai, X.; Swamy, S.N.; Ahn, K.S.; Kumar, A.P.; Tan, B.K.; et al. Potential role of signal transducer and activator of transcription (STAT)3 signaling pathway in inflammation, survival, proliferation and invasion of hepatocellular carcinoma. Biochim. Biophys. Acta 2013, 1835, 46-60.

127. Aggarwal, B.B.; Sethi, G.; Ahn, K.S.; Sandur, S.K.; Pandey, M.K.; Kunnumakkara, A.B.; Sung, B.; Ichikawa, H. Targeting signal-transducer-and-activator-of-transcription-3 for prevention and therapy of cancer: Modern target but ancient solution. Ann. N. Y. Acad. Sci. 2006, 1091, 151-169.

128. Taub, R. Hepatoprotection via the IL-6/Stat3 pathway. J. Clin. Investig. 2003, 112, 978-980.

129. Costa, R.H.; Kalinichenko, V.V.; Holterman, A.X.; Wang, X. Transcription factors in liver development, differentiation, and regeneration. Hepatology 2003, 38, 1331-1347.

130. Darnell, J.E., Jr.; Kerr, I.M.; Stark, G.R. Jak-STAT pathways and transcriptional activation in response to IFNs and other extracellular signaling proteins. Science 1994, 264, 1415-1421.

131. Akira, S.; Nishio, Y.; Inoue, M.; Wang, X.J.; Wei, S.; Matsusaka, T.; Yoshida, K.; Sudo, T.; Naruto, M.; Kishimoto, T. Molecular cloning of APRF, a novel IFN-stimulated gene factor 3 p91-related transcription factor involved in the gp130-mediated signaling pathway. Cell 1994, 77, 63-71.

132. Hibi, M.; Murakami, M.; Saito, M.; Hirano, T.; Taga, T.; Kishimoto, T. Molecular cloning and expression of an IL-6 signal transducer, gp130. Cell 1990, 63, 1149-1157.

133. Hirano, T.; Nakajima, K.; Hibi, M. Signaling mechanisms through gp130: A model of the cytokine system. Cytokine Growth Factor Rev. 1997, 8, 241-252.

134. Naugler, W.E.; Sakurai, T.; Kim, S.; Maeda, S.; Kim, K.; Elsharkawy, A.M.; Karin, M. Gender disparity in liver cancer due to sex differences in MyD88-dependent IL-6 production. Science 2007, 317, 121-124. 
135. Grandis, J.R.; Drenning, S.D.; Chakraborty, A.; Zhou, M.Y.; Zeng, Q.; Pitt, A.S.; Tweardy, D.J. Requirement of Stat 3 but not Stat1 activation for epidermal growth factor receptor- mediated cell growth In vitro. J. Clin. Investig. 1998, 102, 1385-1392.

136. Carlesso, N.; Frank, D.A.; Griffin, J.D. Tyrosyl phosphorylation and DNA binding activity of signal transducers and activators of transcription (STAT) proteins in hematopoietic cell lines transformed by Bcr/Abl. J. Exp. Med. 1996, 183, 811-820.

137. Weber-Nordt, R.M.; Egen, C.; Wehinger, J.; Ludwig, W.; Gouilleux-Gruart, V.; Mertelsmann, R.; Finke, J. Constitutive activation of STAT proteins in primary lymphoid and myeloid leukemia cells and in Epstein-Barr virus (EBV)-related lymphoma cell lines. Blood 1996, 88, 809-816.

138. Bharti, A.C.; Donato, N.; Aggarwal, B.B. Curcumin (diferuloylmethane) inhibits constitutive and IL-6-inducible STAT3 phosphorylation in human multiple myeloma cells. J. Immunol. 2003, 171, 3863-3871.

139. Bharti, A.C.; Shishodia, S.; Reuben, J.M.; Weber, D.; Alexanian, R.; Raj-Vadhan, S.; Estrov, Z.; Talpaz, M.; Aggarwal, B.B. Nuclear factor-kappaB and STAT3 are constitutively active in $\mathrm{CD} 138+$ cells derived from multiple myeloma patients, and suppression of these transcription factors leads to apoptosis. Blood 2004, 103, 3175-3184.

140. Uddin, S.; Hussain, A.R.; Manogaran, P.S.; Al-Hussein, K.; Platanias, L.C.; Gutierrez, M.I.; Bhatia, K.G. Curcumin suppresses growth and induces apoptosis in primary effusion lymphoma. Oncogene 2005, 24, 7022-7030.

141. Rajasingh, J.; Raikwar, H.P.; Muthian, G.; Johnson, C.; Bright, J.J. Curcumin induces growth-arrest and apoptosis in association with the inhibition of constitutively active JAK-STAT pathway in T cell leukemia. Biochem. Biophys. Res. Commun. 2006, 340, 359-368.

142. Chakravarti, N.; Myers, J.N.; Aggarwal, B.B. Targeting constitutive and interleukin-6-inducible signal transducers and activators of transcription 3 pathway in head and neck squamous cell carcinoma cells by curcumin (diferuloylmethane). Int. J. Cancer 2006, 119, 1268-1275.

143. Blasius, R.; Reuter, S.; Henry, E.; Dicato, M.; Diederich, M. Curcumin regulates signal transducer and activator of transcription (STAT) expression in K562 cells. Biochem. Pharmacol. 2006, 72, 1547-1554.

144. Poma, P.; Notarbartolo, M.; Labbozzetta, M.; Maurici, A.; Carina, V.; Alaimo, A.; Rizzi, M.; Simoni, D.; D'Alessandro, N. The antitumor activities of curcumin and of its isoxazole analogue are not affected by multiple gene expression changes in an MDR model of the MCF-7 breast cancer cell line: Analysis of the possible molecular basis. Int. J. Mol. Med. 2007, 20, 329-335.

145. Mackenzie, G.G.; Queisser, N.; Wolfson, M.L.; Fraga, C.G.; Adamo, A.M.; Oteiza, P.I. Curcumin induces cell-arrest and apoptosis in association with the inhibition of constitutively active NF-kappaB and STAT3 pathways in Hodgkin's lymphoma cells. Int. J. Cancer 2008, 123, 56-65.

146. Ghosh, A.K.; Kay, N.E.; Secreto, C.R.; Shanafelt, T.D. Curcumin inhibits prosurvival pathways in chronic lymphocytic leukemia B cells and may overcome their stromal protection in combination with EGCG. Clin. Cancer Res. 2009, 15, 1250-1258.

147. Park, J.; Ayyappan, V.; Bae, E.K.; Lee, C.; Kim, B.S.; Kim, B.K.; Lee, Y.Y.; Ahn, K.S.; Yoon, S.S. Curcumin in combination with bortezomib synergistically induced apoptosis in human multiple myeloma U266 cells. Mol. Oncol. 2008, 2, 317-326. 
148. Friedman, L.; Lin, L.; Ball, S.; Bekaii-Saab, T.; Fuchs, J.; Li, P.K.; Li, C.; Lin, J. Curcumin analogues exhibit enhanced growth suppressive activity in human pancreatic cancer cells. Anticancer Drugs 2009, 20, 444-449.

149. Glienke, W.; Maute, L.; Wicht, J.; Bergmann, L. Curcumin inhibits constitutive STAT3 phosphorylation in human pancreatic cancer cell lines and downregulation of survivin/BIRC5 gene expression. Cancer Investig. 2010, 28, 166-171.

150. Seo, J.H.; Jeong, K.J.; Oh, W.J.; Sul, H.J.; Sohn, J.S.; Kim, Y.K.; Cho do, Y.; Kang, J.K.; Park, C.G.; Lee, H.Y. Lysophosphatidic acid induces STAT3 phosphorylation and ovarian cancer cell motility: Their inhibition by curcumin. Cancer Lett. 2010, 288, 50-56.

151. Saydmohammed, M.; Joseph, D.; Syed, V. Curcumin suppresses constitutive activation of STAT-3 by up-regulating protein inhibitor of activated STAT-3 (PIAS-3) in ovarian and endometrial cancer cells. J. Cell Biochem. 2010, 110, 447-456.

152. Bill, M.A.; Bakan, C.; Benson, D.M., Jr.; Fuchs, J.; Young, G.; Lesinski, G.B. Curcumin induces proapoptotic effects against human melanoma cells and modulates the cellular response to immunotherapeutic cytokines. Mol. Cancer Ther. 2009, 8, 2726-2735.

153. Wang, L.; Shen, Y.; Song, R.; Sun, Y.; Xu, J.; Xu, Q. An anticancer effect of curcumin mediated by down-regulating phosphatase of regenerating liver-3 expression on highly metastatic melanoma cells. Mol. Pharmacol. 2009, 76, 1238-1245.

154. Senft, C.; Polacin, M.; Priester, M.; Seifert, V.; Kogel, D.; Weissenberger, J. The nontoxic natural compound Curcumin exerts anti-proliferative, anti-migratory, and anti-invasive properties against malignant gliomas. BMC Cancer 2010, 10, 491.

155. Weissenberger, J.; Priester, M.; Bernreuther, C.; Rakel, S.; Glatzel, M.; Seifert, V.; Kogel, D. Dietary curcumin attenuates glioma growth in a syngeneic mouse model by inhibition of the JAK1,2/STAT3 signaling pathway. Clin. Cancer Res. 2010, 16, 5781-5795.

156. Alexandrow, M.G.; Song, L.J.; Altiok, S.; Gray, J.; Haura, E.B.; Kumar, N.B. Curcumin: A novel Stat3 pathway inhibitor for chemoprevention of lung cancer. Eur. J. Cancer Prev. 2012, 21, 407-412.

157. Yang, C.L.; Liu, Y.Y.; Ma, Y.G.; Xue, Y.X.; Liu, D.G.; Ren, Y.; Liu, X.B.; Li, Y.; Li, Z. Curcumin blocks small cell lung cancer cells migration, invasion, angiogenesis, cell cycle and neoplasia through Janus kinase-STAT3 signalling pathway. PLoS One 2012, 7, e37960.

158. Chiablaem, K.; Lirdprapamongkol, K.; Keeratichamroen, S.; Surarit, R.; Svasti, J. Curcumin suppresses vasculogenic mimicry capacity of hepatocellular carcinoma cells through STAT3 and PI3K/AKT inhibition. Anticancer Res. 2014, 34, 1857-1864.

159. Logan, C.Y.; Nusse, R. The Wnt signaling pathway in development and disease. Annu. Rev. Cell Dev. Biol. 2004, 20, 781-810.

160. Clevers, H. Wnt/beta-catenin signaling in development and disease. Cell 2006, 127, 469-480.

161. Polakis, P. The many ways of Wnt in cancer. Curr. Opin. Genet Dev. 2007, 17, 45-51.

162. Jaiswal, A.S.; Marlow, B.P.; Gupta, N.; Narayan, S. Beta-catenin-mediated transactivation and cell-cell adhesion pathways are important in curcumin (diferuylmethane)-induced growth arrest and apoptosis in colon cancer cells. Oncogene 2002, 21, 8414-8427. 
163. Narayan, S. Curcumin, a multi-functional chemopreventive agent, blocks growth of colon cancer cells by targeting beta-catenin-mediated transactivation and cell-cell adhesion pathways. J. Mol. Histol. 2004, 35, 301-307.

164. Park, C.H.; Hahm, E.R.; Park, S.; Kim, H.K.; Yang, C.H. The inhibitory mechanism of curcumin and its derivative against beta-catenin/Tcf signaling. FEBS Lett. 2005, 579, 2965-2971.

165. Ryu, M.J.; Cho, M.; Song, J.Y.; Yun, Y.S.; Choi, I.W.; Kim, D.E.; Park, B.S.; Oh, S. Natural derivatives of curcumin attenuate the Wnt/beta-catenin pathway through down-regulation of the transcriptional coactivator p300. Biochem. Biophys. Res. Commun. 2008, 377, 1304-1308.

166. Prasad, C.P.; Rath, G.; Mathur, S.; Bhatnagar, D.; Ralhan, R. Potent growth suppressive activity of curcumin in human breast cancer cells: Modulation of Wnt/beta-catenin signaling. Chem. Biol. Interact. 2009, 181, 263-271.

167. Leow, P.C.; Tian, Q.; Ong, Z.Y.; Yang, Z.; Ee, P.L. Antitumor activity of natural compounds, curcumin and PKF118-310, as Wnt/beta-catenin antagonists against human osteosarcoma cells. Investig. New Drugs 2010, 28, 766-782.

168. Choi, H.Y.; Lim, J.E.; Hong, J.H. Curcumin interrupts the interaction between the androgen receptor and $\mathrm{Wnt} /$ beta-catenin signaling pathway in LNCaP prostate cancer cells. Prostate Cancer Prostatic Dis. 2010, 13, 343-349.

169. Teiten, M.H.; Gaascht, F.; Cronauer, M.; Henry, E.; Dicato, M.; Diederich, M. Anti-proliferative potential of curcumin in androgen-dependent prostate cancer cells occurs through modulation of the Wingless signaling pathway. Int. J. Oncol. 2011, 38, 603-611.

170. Sundram, V.; Chauhan, S.C.; Ebeling, M.; Jaggi, M. Curcumin attenuates beta-catenin signaling in prostate cancer cells through activation of protein kinase D1. PLoS One 2012, 7, e35368.

171. Xu, M.X.; Zhao, L.; Deng, C.; Yang, L.; Wang, Y.; Guo, T.; Li, L.; Lin, J.; Zhang, L. Curcumin suppresses proliferation and induces apoptosis of human hepatocellular carcinoma cells via the wnt signaling pathway. Int. J. Oncol. 2013, 43, 1951-1959.

172. He, M.; Li, Y.; Zhang, L.; Li, L.; Shen, Y.; Lin, L.; Zheng, W.; Chen, L.; Bian, X.; Ng, H.K.; et al. Curcumin suppresses cell proliferation through inhibition of the Wnt/beta-catenin signaling pathway in medulloblastoma. Oncol. Rep. 2014, 32, 173-180.

173. Lu, Y.; Wei, C.; Xi, Z. Curcumin suppresses proliferation and invasion in non-small cell lung cancer by modulation of MTA1-mediated Wnt/beta-catenin pathway. In Vitro Cell. Dev. Biol. Anim. 2014, 50, 840-850.

174. Hayes, J.D.; McMahon, M.; Chowdhry, S.; Dinkova-Kostova, A.T. Cancer chemoprevention mechanisms mediated through the Keap1-Nrf2 pathway. Antioxid. Redox Signal. 2010, 13, 1713-1748.

175. Klaassen, C.D.; Reisman, S.A. Nrf2 the rescue: Effects of the antioxidative/electrophilic response on the liver. Toxicol. Appl. Pharmacol. 2010, 244, 57-65.

176. Martin-Montalvo, A.; Villalba, J.M.; Navas, P.; de Cabo, R. NRF2, cancer and calorie restriction. Oncogene 2011, 30, 505-520.

177. Balogun, E.; Hoque, M.; Gong, P.; Killeen, E.; Green, C.J.; Foresti, R.; Alam, J.; Motterlini, R. Curcumin activates the haem oxygenase-1 gene via regulation of $\mathrm{Nrf} 2$ and the antioxidant-responsive element. Biochem. J. 2003, 371 (Pt. 3), 887-895. 
178. Eggler, A.L.; Gay, K.A.; Mesecar, A.D. Molecular mechanisms of natural products in chemoprevention: Induction of cytoprotective enzymes by Nrf2. Mol. Nutr. Food Res. 2008, 52 (Suppl. 1), S84-S94.

179. Rushworth, S.A.; Ogborne, R.M.; Charalambos, C.A.; O’Connell, M.A. Role of protein kinase C delta in curcumin-induced antioxidant response element-mediated gene expression in human monocytes. Biochem. Biophys. Res. Commun. 2006, 341, 1007-1016.

180. McNally, S.J.; Harrison, E.M.; Ross, J.A.; Garden, O.J.; Wigmore, S.J. Curcumin induces heme oxygenase 1 through generation of reactive oxygen species, p38 activation and phosphatase inhibition. Int. J. Mol. Med. 2007, 19, 165-172.

181. Khor, T.O.; Huang, Y.; Wu, T.Y.; Shu, L.; Lee, J.; Kong, A.N. Pharmacodynamics of curcumin as DNA hypomethylation agent in restoring the expression of $\mathrm{Nrf} 2$ via promoter $\mathrm{CpGs}$ demethylation. Biochem. Pharmacol. 2011, 82, 1073-1078.

182. Chen, B.; Zhang, Y.; Wang, Y.; Rao, J.; Jiang, X.; Xu, Z. Curcumin inhibits proliferation of breast cancer cells through Nrf2-mediated down-regulation of Fen1 expression. J. Steroid. Biochem. Mol. Biol. 2014, 143, 11-18.

183. Aggarwal, B.B.; Gupta, S.C.; Kim, J.H. Historical perspectives on tumor necrosis factor and its superfamily: 25 years later, a golden journey. Blood 2012, 119, 651-665.

184. Sethi, G.; Sung, B.; Aggarwal, B.B. TNF: A master switch for inflammation to cancer. Front Biosci. 2008, 13, 5094-5107.

185. Sethi, G.; Sung, B.; Kunnumakkara, A.B.; Aggarwal, B.B. Targeting TNF for Treatment of Cancer and Autoimmunity. Adv. Exp. Med. Biol. 2009, 647, 37-51.

186. Sugarman, B.J.; Aggarwal, B.B.; Hass, P.E.; Figari, I.S.; Palladino, M.A., Jr.; Shepard, H.M. Recombinant human tumor necrosis factor-alpha: Effects on proliferation of normal and transformed cells in vitro. Science 1985, 230, 943-945.

187. Shanmugam, M.K.; Sethi, G. Role of epigenetics in inflammation-associated diseases. Subcell Biochem. 2013, 61, 627-657.

188. Kumar, A.; Dhawan, S.; Hardegen, N.J.; Aggarwal, B.B. Curcumin (Diferuloylmethane) inhibition of tumor necrosis factor (TNF)-mediated adhesion of monocytes to endothelial cells by suppression of cell surface expression of adhesion molecules and of nuclear factor-kappaB activation. Biochem. Pharmacol. 1998, 55, 775-783.

189. Baek, O.S.; Kang, O.H.; Choi, Y.A.; Choi, S.C.; Kim, T.H.; Nah, Y.H.; Kwon, D.Y.; Kim, Y.K.; Kim, Y.H.; Bae, K.H.; et al. Curcumin inhibits protease-activated receptor-2 and -4-mediated mast cell activation. Clin. Chim. Acta 2003, 338, 135-141.

190. Cheung, K.L.; Khor, T.O.; Kong, A.N. Synergistic effect of combination of phenethyl isothiocyanate and sulforaphane or curcumin and sulforaphane in the inhibition of inflammation. Pharm. Res. 2009, 26, 224-231.

191. Teiten, M.H.; Eifes, S.; Reuter, S.; Duvoix, A.; Dicato, M.; Diederich, M. Gene expression profiling related to anti-inflammatory properties of curcumin in K562 leukemia cells. Ann. N. Y. Acad. Sci. 2009, 1171, 391-398. 
192. Lee, J.C.; Kinniry, P.A.; Arguiri, E.; Serota, M.; Kanterakis, S.; Chatterjee, S.; Solomides, C.C.; Javvadi, P.; Koumenis, C.; Cengel, K.A.; Christofidou-Solomidou, M. Dietary curcumin increases antioxidant defenses in lung, ameliorates radiation-induced pulmonary fibrosis, and improves survival in mice. Radiat. Res. 2010, 173, 590-601.

193. Gupta, S.C.; Patchva, S.; Aggarwal, B.B. Therapeutic roles of curcumin: Lessons learned from clinical trials. AAPS J. 2013, 15, 195-218.

194. Vaughan, R.A.; Garcia-Smith, R.; Dorsey, J.; Griffith, J.K.; Bisoffi, M.; Trujillo, K.A. Tumor necrosis factor alpha induces Warburg-like metabolism and is reversed by anti-inflammatory curcumin in breast epithelial cells. Int. J. Cancer 2013, 133, 2504-2510.

195. Das, L.; Vinayak, M. Long-term effect of curcumin down-regulates expression of tumor necrosis factor-alpha and interleukin-6 via modulation of E26 transformation-specific protein and nuclear factor-kappaB transcription factors in livers of lymphoma bearing mice. Leuk Lymphoma 2014, $55,2627-2636$.

196. Gupta, S.C.; Tyagi, A.K.; Deshmukh-Taskar, P.; Hinojosa, M.; Prasad, S.; Aggarwal, B.B. Downregulation of tumor necrosis factor and other proinflammatory biomarkers by polyphenols. Arch. Biochem. Biophys. 2014, 559C, 91-99.

197. Rennolds, J.; Malireddy, S.; Hassan, F.; Tridandapani, S.; Parinandi, N.; Boyaka, P.N.; Cormet-Boyaka, E. Curcumin regulates airway epithelial cell cytokine responses to the pollutant cadmium. Biochem. Biophys. Res. Commun. 2012, 417, 256-261.

198. Menon, V.P.; Sudheer, A.R. Antioxidant and anti-inflammatory properties of curcumin. Adv. Exp. Med. Biol. 2007, 595, 105-125.

199. Bengmark, S. Curcumin, an atoxic antioxidant and natural NFkappaB, cyclooxygenase-2, lipooxygenase, and inducible nitric oxide synthase inhibitor: A shield against acute and chronic diseases. JPEN J. Parenter Enter. Nutr. 2006, 30, 45-51.

200. Chan, M.M.; Huang, H.I.; Fenton, M.R.; Fong, D. In vivo inhibition of nitric oxide synthase gene expression by curcumin, a cancer preventive natural product with anti-inflammatory properties. Biochem. Pharmacol. 1998, 55, 1955-1962.

201. Murakami, A.; Furukawa, I.; Miyamoto, S.; Tanaka, T.; Ohigashi, H. Curcumin combined with turmerones, essential oil components of turmeric, abolishes inflammation-associated mouse colon carcinogenesis. Biofactors 2013, 39, 221-232.

202. Saw, C.L.; Huang, Y.; Kong, A.N. Synergistic anti-inflammatory effects of low doses of curcumin in combination with polyunsaturated fatty acids: Docosahexaenoic acid or eicosapentaenoic acid. Biochem. Pharmacol. 2010, 79, 421-430.

203. Seger, R.; Krebs, E.G. The MAPK signaling cascade. FASEB J. 1995, 9, 726-735.

204. Lev-Ari, S.; Starr, A.; Vexler, A.; Karaush, V.; Loew, V.; Greif, J.; Fenig, E.; Aderka, D.; Ben-Yosef, R. Inhibition of pancreatic and lung adenocarcinoma cell survival by curcumin is associated with increased apoptosis, down-regulation of COX-2 and EGFR and inhibition of Erk1/2 activity. Anticancer Res. 2006, 26, 4423-4430.

205. Aoki, H.; Takada, Y.; Kondo, S.; Sawaya, R.; Aggarwal, B.B.; Kondo, Y. Evidence that curcumin suppresses the growth of malignant gliomas in vitro and in vivo through induction of autophagy: Role of Akt and extracellular signal-regulated kinase signaling pathways. Mol. Pharmacol. 2007, 72, 29-39. 
206. Hu, M.; Du, Q.; Vancurova, I.; Lin, X.; Miller, E.J.; Simms, H.H.; Wang, P. Proapoptotic effect of curcumin on human neutrophils: Activation of the p38 mitogen-activated protein kinase pathway. Crit. Care Med. 2005, 33, 2571-2578.

207. Salh, B.; Assi, K.; Templeman, V.; Parhar, K.; Owen, D.; Gomez-Munoz, A.; Jacobson, K. Curcumin attenuates DNB-induced murine colitis. Am. J. Physiol. Gastrointest. Liver Physiol. 2003, 285, G235-G243.

208. Slamon, D.J.; Clark, G.M.; Wong, S.G.; Levin, W.J.; Ullrich, A.; McGuire, W.L. Human breast cancer: Correlation of relapse and survival with amplification of the HER-2/neu oncogene. Science 1987, 235, 177-182.

209. Dorai, T.; Gehani, N.; Katz, A. Therapeutic potential of curcumin in human prostate cancer. II. Curcumin inhibits tyrosine kinase activity of epidermal growth factor receptor and depletes the protein. Mol. Urol. 2000, 4, 1-6.

210. Li, S.; Liu, Z.; Zhu, F.; Fan, X.; Wu, X.; Zhao, H.; Jiang, L. Curcumin lowers erlotinib resistance in non-small cell lung carcinoma cells with mutated EGF receptor. Oncol. Res. 2014, 21, 137-144.

211. Lee, J.Y.; Lee, Y.M.; Chang, G.C.; Yu, S.L.; Hsieh, W.Y.; Chen, J.J.; Chen, H.W.; Yang, P.C. Curcumin induces EGFR degradation in lung adenocarcinoma and modulates p38 activation in intestine: The versatile adjuvant for gefitinib therapy. PLoS One 2011, 6, e23756.

212. Jiang, A.P.; Zhou, D.H.; Meng, X.L.; Zhang, A.P.; Zhang, C.; Li, X.T.; Feng, Q. Down-regulation of epidermal growth factor receptor by curcumin-induced UBE1L in human bronchial epithelial cells. J. Nutr. Biochem. 2014, 25, 241-249.

213. Wang, S.; Yu, S.; Shi, W.; Ge, L.; Yu, X.; Fan, J.; Zhang, J. Curcumin inhibits the migration and invasion of mouse hepatoma Hca-F cells through down-regulating caveolin-1 expression and epidermal growth factor receptor signaling. IUBMB Life 2011, 63, 775-782.

214. Soung, Y.H.; Chung, J. Curcumin inhibition of the functional interaction between integrin alpha6beta4 and the epidermal growth factor receptor. Mol. Cancer Ther. 2011, 10, 883-891.

215. Patel, B.B.; Gupta, D.; Elliott, A.A.; Sengupta, V.; Yu, Y.; Majumdar, A.P. Curcumin targets FOLFOX-surviving colon cancer cells via inhibition of EGFRs and IGF-1R. Anticancer Res. 2010, 30, 319-325.

216. Patel, B.B.; Sengupta, R.; Qazi, S.; Vachhani, H.; Yu, Y.; Rishi, A.K.; Majumdar, A.P. Curcumin enhances the effects of 5-fluorouracil and oxaliplatin in mediating growth inhibition of colon cancer cells by modulating EGFR and IGF-1R. Int. J. Cancer 2008, 122, 267-273.

217. Ji, C.; Cao, C.; Lu, S.; Kivlin, R.; Amaral, A.; Kouttab, N.; Yang, H.; Chu, W.; Bi, Z.; Di, W.; et al. Curcumin attenuates EGF-induced AQP3 up-regulation and cell migration in human ovarian cancer cells. Cancer Chemother. Pharmacol. 2008, 62, 857-865.

218. Mukhopadhyay, A.; Banerjee, S.; Stafford, L.J.; Xia, C.; Liu, M.; Aggarwal, B.B. Curcumin-induced suppression of cell proliferation correlates with down-regulation of cyclin D1 expression and CDK4-mediated retinoblastoma protein phosphorylation. Oncogene 2002, 21, 8852-8861.

219. Moragoda, L.; Jaszewski, R.; Majumdar, A.P. Curcumin induced modulation of cell cycle and apoptosis in gastric and colon cancer cells. Anticancer Res. 2001, 21, 873-878. 
220. Park, M.J.; Kim, E.H.; Park, I.C.; Lee, H.C.; Woo, S.H.; Lee, J.Y.; Hong, Y.J.; Rhee, C.H.; Choi, S.H.; Shim, B.S.; et al. Curcumin inhibits cell cycle progression of immortalized human umbilical vein endothelial (ECV304) cells by up-regulating cyclin-dependent kinase inhibitor, p21WAF1/CIP1, p27KIP1 and p53. Int. J. Oncol. 2002, 21, 379-383.

221. Hour, T.C.; Chen, J.; Huang, C.Y.; Guan, J.Y.; Lu, S.H.; Pu, Y.S. Curcumin enhances cytotoxicity of chemotherapeutic agents in prostate cancer cells by inducing p21(WAF1/CIP1) and C/EBPbeta expressions and suppressing NF-kappaB activation. Prostate 2002, 51, 211-218.

222. Liontas, A.; Yeger, H. Curcumin and resveratrol induce apoptosis and nuclear translocation and activation of p53 in human neuroblastoma. Anticancer Res. 2004, 24, 987-998.

223. Schaaf, C.; Shan, B.; Buchfelder, M.; Losa, M.; Kreutzer, J.; Rachinger, W.; Stalla, G.K.; Schilling, T.; Arzt, E.; Perone, M.J.; et al. Curcumin acts as anti-tumorigenic and hormone-suppressive agent in murine and human pituitary tumour cells in vitro and in vivo. Endocr. Relat. Cancer 2009, 16, 1339-1350.

224. Zhou, Q.M.; Wang, X.F.; Liu, X.J.; Zhang, H.; Lu, Y.Y.; Su, S.B. Curcumin enhanced antiproliferative effect of mitomycin $\mathrm{C}$ in human breast cancer MCF-7 cells in vitro and in vivo. Acta Pharmacol. Sin. 2011, 32, 1402-1410.

225. Li, Z.C.; Zhang, L.M.; Wang, H.B.; Ma, J.X.; Sun, J.Z. Curcumin inhibits lung cancer progression and metastasis through induction of FOXO1. Tumour Biol. 2014, 35, 111-116.

226. Dey, A.; Tergaonkar, V.; Lane, D.P. Double-edged swords as cancer therapeutics: Simultaneously targeting p53 and NF-kappaB pathways. Nat. Rev. Drug Discov. 2008, 7, 1031-1040.

227. Tergaonkar, V. p53 and NFkappaB: Fresh breath in the cross talk. Cell Res. 2009, 19, 1313-1315.

228. Jee, S.H.; Shen, S.C.; Tseng, C.R.; Chiu, H.C.; Kuo, M.L. Curcumin induces a p53-dependent apoptosis in human basal cell carcinoma cells. J. Investig. Dermatol. 1998, 111, 656-661.

229. Choudhuri, T.; Pal, S.; Agwarwal, M.L.; Das, T.; Sa, G. Curcumin induces apoptosis in human breast cancer cells through p53-dependent Bax induction. FEBS Lett. 2002, 512, 334-340.

230. Choudhuri, T.; Pal, S.; Das, T.; Sa, G. Curcumin selectively induces apoptosis in deregulated cyclin D1-expressed cells at G2 phase of cell cycle in a p53-dependent manner. J. Biol. Chem. 2005, 280, 20059-20068.

231. Song, G.; Mao, Y.B.; Cai, Q.F.; Yao, L.M.; Ouyang, G.L.; Bao, S.D. Curcumin induces human HT-29 colon adenocarcinoma cell apoptosis by activating p53 and regulating apoptosis-related protein expression. Braz. J. Med. Biol. Res. 2005, 38, 1791-1798.

232. Howells, L.M.; Mitra, A.; Manson, M.M. Comparison of oxaliplatin- and curcumin-mediated antiproliferative effects in colorectal cell lines. Int. J. Cancer 2007, 121, 175-183.

233. He, Z.Y.; Shi, C.B.; Wen, H.; Li, F.L.; Wang, B.L.; Wang, J. Upregulation of p53 expression in patients with colorectal cancer by administration of curcumin. Cancer Investig. 2011, 29, 208-213.

234. Shi, M.; Cai, Q.; Yao, L.; Mao, Y.; Ming, Y.; Ouyang, G. Antiproliferation and apoptosis induced by curcumin in human ovarian cancer cells. Cell Biol. Int. 2006, 30, 221-226.

235. Weir, N.M.; Selvendiran, K.; Kutala, V.K.; Tong, L.; Vishwanath, S.; Rajaram, M.; Tridandapani, S.; Anant, S.; Kuppusamy, P. Curcumin induces G2/M arrest and apoptosis in cisplatin-resistant human ovarian cancer cells by modulating Akt and p38 MAPK. Cancer Biol. Ther. 2007, 6, 178-184. 
236. Wu, J.; Tang, Q.; Zhao, S.; Zheng, F.; Wu, Y.; Tang, G.; Hahn, S.S. Extracellular signal-regulated kinase signaling-mediated induction and interaction of FOXO3a and p53 contribute to the inhibition of nasopharyngeal carcinoma cell growth by curcumin. Int. J. Oncol. 2014, 45, 95-103.

237. Li, M.; Zhang, Z.; Hill, D.L.; Wang, H.; Zhang, R. Curcumin, a dietary component, has anticancer, chemosensitization, and radiosensitization effects by down-regulating the MDM2 oncogene through the PI3K/mTOR/ETS2 pathway. Cancer Res. 2007, 67, 1988-1996.

238. Shankar, S.; Srivastava, R.K. Involvement of Bcl-2 family members, phosphatidylinositol 3'-kinase/AKT and mitochondrial p53 in curcumin (diferulolylmethane)-induced apoptosis in prostate cancer. Int. J. Oncol. 2007, 30, 905-918.

239. Liu, E.; Wu, J.; Cao, W.; Zhang, J.; Liu, W.; Jiang, X.; Zhang, X. Curcumin induces G2/M cell cycle arrest in a p53-dependent manner and upregulates ING4 expression in human glioma. J. Neurooncol. 2007, 85, 263-270.

240. William, B.M.; Goodrich, A.; Peng, C.; Li, S. Curcumin inhibits proliferation and induces apoptosis of leukemic cells expressing wild-type or T315I-BCR-ABL and prolongs survival of mice with acute lymphoblastic leukemia. Hematology 2008, 13, 333-343.

241. Suphim, B.; Prawan, A.; Kukongviriyapan, U.; Kongpetch, S.; Buranrat, B.; Kukongviriyapan, V. Redox modulation and human bile duct cancer inhibition by curcumin. Food Chem. Toxicol. 2010, 48, 2265-2272.

242. Seo, B.R.; Min, K.J.; Cho, I.J.; Kim, S.C.; Kwon, T.K. Curcumin significantly enhances dual PI3K/Akt and mTOR inhibitor NVP-BEZ235-induced apoptosis in human renal carcinoma Caki cells through down-regulation of p53-dependent Bcl-2 expression and inhibition of Mcl-1 protein stability. PLoS One 2014, 9, e95588.

243. Dey, A.; Wong, E.T.; Bist, P.; Tergaonkar, V.; Lane, D.P. Nutlin-3 inhibits the NFkappaB pathway in a p53-dependent manner: Implications in lung cancer therapy. Cell Cycle 2007, 6, 2178-2185.

244. Radhakrishna Pillai, G.; Srivastava, A.S.; Hassanein, T.I.; Chauhan, D.P.; Carrier, E. Induction of apoptosis in human lung cancer cells by curcumin. Cancer Lett. 2004, 208, 163-170.

245. Bush, J.A.; Cheung, K.J., Jr.; Li, G. Curcumin induces apoptosis in human melanoma cells through a Fas receptor/caspase-8 pathway independent of p53. Exp. Cell Res. 2001, 271, 305-314.

246. Chiu, T.L.; Su, C.C. Curcumin inhibits proliferation and migration by increasing the Bax to Bcl-2 ratio and decreasing NF-kappaBp65 expression in breast cancer MDA-MB-231 cells. Int. J. Mol. Med. 2009, 23, 469-475.

247. Shehzad, A.; Lee, J.; Huh, T.L.; Lee, Y.S. Curcumin induces apoptosis in human colorectal carcinoma (HCT-15) cells by regulating expression of Prp4 and p53. Mol. Cells 2013, 35, 526-532.

248. Watson, J.L.; Greenshields, A.; Hill, R.; Hilchie, A.; Lee, P.W.; Giacomantonio, C.A.; Hoskin, D.W. Curcumin-induced apoptosis in ovarian carcinoma cells is p53-independent and involves p38 mitogen-activated protein kinase activation and downregulation of Bcl-2 and survivin expression and Akt signaling. Mol. Carcinog. 2010, 49, 13-24.

249. Yan, G.; Graham, K.; Lanza-Jacoby, S. Curcumin enhances the anticancer effects of trichostatin a in breast cancer cells. Mol. Carcinog. 2013, 52, 404-411.

250. Lin, L.I.; Ke, Y.F.; Ko, Y.C.; Lin, J.K. Curcumin inhibits SK-Hep-1 hepatocellular carcinoma cell invasion in vitro and suppresses matrix metalloproteinase-9 secretion. Oncology 1998, 55, 349-353. 
251. Kumar, D.; Kumar, M.; Saravanan, C.; Singh, S.K. Curcumin: A potential candidate for matrix metalloproteinase inhibitors. Expert Opin. Ther. Targets 2012, 16, 959-972.

252. Su, C.C.; Chen, G.W.; Lin, J.G.; Wu, L.T.; Chung, J.G. Curcumin inhibits cell migration of human colon cancer colo 205 cells through the inhibition of nuclear factor kappa B /p65 and down-regulates cyclooxygenase-2 and matrix metalloproteinase-2 expressions. Anticancer Res. 2006, 26, 1281-1288.

253. Tan, T.W.; Tsai, H.R.; Lu, H.F.; Lin, H.L.; Tsou, M.F.; Lin, Y.T.; Tsai, H.Y.; Chen, Y.F.; Chung, J.G. Curcumin-induced cell cycle arrest and apoptosis in human acute promyelocytic leukemia HL-60 cells via MMP changes and caspase-3 activation. Anticancer Res. 2006, 26, 4361-4371.

254. Bachmeier, B.; Nerlich, A.G.; Iancu, C.M.; Cilli, M.; Schleicher, E.; Vene, R.; Dell'Eva, R.; Jochum, M.; Albini, A.; Pfeffer, U. The chemopreventive polyphenol Curcumin prevents hematogenous breast cancer metastases in immunodeficient mice. Cell Physiol. Biochem. 2007, 19, 137-152.

255. Mitra, A.; Chakrabarti, J.; Banerji, A.; Chatterjee, A.; Das, B.R. Curcumin, a potential inhibitor of MMP-2 in human laryngeal squamous carcinoma cells HEp2. J. Environ. Pathol. Toxicol. Oncol. 2006, 25, 679-690.

256. Kunnumakkara, A.B.; Diagaradjane, P.; Anand, P.; Harikumar, K.B.; Deorukhkar, A.; Gelovani, J.; Guha, S.; Krishnan, S.; Aggarwal, B.B. Curcumin sensitizes human colorectal cancer to capecitabine by modulation of cyclin D1, COX-2, MMP-9, VEGF and CXCR4 expression in an orthotopic mouse model. Int. J. Cancer 2009, 125, 2187-2197.

257. Abdullah Thani, N.A.; Sallis, B.; Nuttall, R.; Schubert, F.R.; Ahsan, M.; Davies, D.; Purewal, S.; Cooper, A.; Rooprai, H.K. Induction of apoptosis and reduction of MMP gene expression in the U373 cell line by polyphenolics in Aronia melanocarpa and by curcumin. Oncol. Rep. 2012, 28, $1435-1442$.

258. Lin, S.S.; Lai, K.C.; Hsu, S.C.; Yang, J.S.; Kuo, C.L.; Lin, J.P.; Ma, Y.S.; Wu, C.C.; Chung, J.G. Curcumin inhibits the migration and invasion of human A549 lung cancer cells through the inhibition of matrix metalloproteinase-2 and -9 and Vascular Endothelial Growth Factor (VEGF). Cancer Lett. 2009, 285, 127-133.

259. Chen, Q.Y.; Zheng, Y.; Jiao, D.M.; Chen, F.Y.; Hu, H.Z.; Wu, Y.Q.; Song, J.; Yan, J.; Wu, L.J.; Lv, G.Y. Curcumin inhibits lung cancer cell migration and invasion through Rac1-dependent signaling pathway. J. Nutr. Biochem. 2014, 25, 177-185.

260. Xie, Y.Q.; Wu, X.B.; Tang, S.Q. Curcumin treatment alters ERK-1/2 signaling in vitro and inhibits nasopharyngeal carcinoma proliferation in mouse xenografts. Int. J. Clin. Exp. Med. 2014, 7, $108-114$.

261. Shen, F.; Cai, W.S.; Li, J.L.; Feng, Z.; Liu, Q.C.; Xiao, H.Q.; Cao, J.; Xu, B. Synergism from the combination of ulinastatin and curcumin offers greater inhibition against colorectal cancer liver metastases via modulating matrix metalloproteinase-9 and E-cadherin expression. Onco Targets Ther. 2014, 7, 305-314.

262. Sinha, D.; Biswas, J.; Sung, B.; Aggarwal, B.B.; Bishayee, A. Chemopreventive and chemotherapeutic potential of curcumin in breast cancer. Curr. Drug Targets 2012, 13, 1799-1819.

263. Nagaraju, G.P.; Aliya, S.; Zafar, S.F.; Basha, R.; Diaz, R.; El-Rayes, B.F. The impact of curcumin on breast cancer. Integr. Biol. (Camb.) 2012, 4, 996-1007. 
264. Zlotogorski, A.; Dayan, A.; Dayan, D.; Chaushu, G.; Salo, T.; Vered, M. Nutraceuticals as new treatment approaches for oral cancer-I: Curcumin. Oral Oncol. 2013, 49, 187-191.

265. Gao, W.; Chan, J.Y.; Wei, W.I.; Wong, T.S. Anti-cancer effects of curcumin on head and neck cancers. Anticancer Agents Med. Chem. 2012, 12, 1110-1116.

266. Wilken, R.; Veena, M.S.; Wang, M.B.; Srivatsan, E.S. Curcumin: A review of anti-cancer properties and therapeutic activity in head and neck squamous cell carcinoma. Mol. Cancer 2011, $10,12$.

267. Darvesh, A.S.; Aggarwal, B.B.; Bishayee, A. Curcumin and liver cancer: A review. Curr. Pharm. Biotechnol. 2012, 13, 218-228.

268. Johnson, J.; de Mejia, E.G. Dietary factors and pancreatic cancer: The role of food bioactive compounds. Mol. Nutr. Food Res. 2011, 55, 58-73.

269. Stan, S.D.; Singh, S.V.; Brand, R.E. Chemoprevention strategies for pancreatic cancer. Nat. Rev. Gastroenterol. Hepatol. 2010, 7, 347-356.

270. Von Low, E.C.; Perabo, F.G.; Siener, R.; Muller, S.C. Review. Facts and fiction of phytotherapy for prostate cancer: A critical assessment of preclinical and clinical data. In Vivo 2007, 21, 189-204.

271. Singh, R.P.; Agarwal, R. Mechanisms of action of novel agents for prostate cancer chemoprevention. Endocr. Relat. Cancer 2006, 13, 751-778.

272. Nambiar, D.; Singh, R.P. Advances in prostate cancer chemoprevention: A translational perspective. Nutr. Cancer 2013, 65 (Suppl. 1), 12-25.

273. Temraz, S.; Mukherji, D.; Shamseddine, A. Potential targets for colorectal cancer prevention. Int. J. Mol. Sci. 2013, 14, 17279-17303.

274. Sareen, R.; Jain, N.; Pandit, V. Curcumin: A boon to colonic diseases. Curr. Drug Targets 2013, $14,1210-1218$.

275. Chung, M.Y.; Lim, T.G.; Lee, K.W. Molecular mechanisms of chemopreventive phytochemicals against gastroenterological cancer development. World J. Gastroenterol. WJG 2013, 19, 984-993.

276. Saha, S.; Adhikary, A.; Bhattacharyya, P.; Das, T.; Sa, G. Death by design: Where curcumin sensitizes drug-resistant tumours. Anticancer Res. 2012, 32, 2567-2584.

277. Norris, L.; Karmokar, A.; Howells, L.; Steward, W.P.; Gescher, A.; Brown, K. The role of cancer stem cells in the anti-carcinogenicity of curcumin. Mol. Nutr. Food Res. 2013, 57, 1630-1637.

278. Schaffer, M.; Schaffer, P.M.; Zidan, J.; Bar Sela, G. Curcuma as a functional food in the control of cancer and inflammation. Curr. Opin. Clin. Nutr. Metab. Care 2011, 14, 588-597.

279. Kuttan, G.; Kumar, K.B.; Guruvayoorappan, C.; Kuttan, R. Antitumor, anti-invasion, and antimetastatic effects of curcumin. Adv. Exp. Med. Biol. 2007, 595, 173-184.

280. Aggarwal, B.B.; Sung, B. Pharmacological basis for the role of curcumin in chronic diseases: An age-old spice with modern targets. Trends Pharmacol. Sci. 2009, 30, 85-94.

281. Park, W.; Amin, A.R.; Chen, Z.G.; Shin, D.M. New perspectives of curcumin in cancer prevention. Cancer Prev. Res. 2013, 6, 387-400.

282. Shehzad, A.; Lee, J.; Lee, Y.S. Curcumin in various cancers. Biofactors 2013, 39, 56-68.

283. Sung, B.; Kunnumakkara, A.B.; Sethi, G.; Anand, P.; Guha, S.; Aggarwal, B.B. Curcumin circumvents chemoresistance in vitro and potentiates the effect of thalidomide and bortezomib against human multiple myeloma in nude mice model. Mol. Cancer Ther. 2009, 8, 959-970. 
284. Shehzad, A.; Lee, Y.S. Molecular mechanisms of curcumin action: Signal transduction. Biofactors 2013, 39, 27-36.

285. Shehzad, A.; Wahid, F.; Lee, Y.S. Curcumin in cancer chemoprevention: Molecular targets, pharmacokinetics, bioavailability, and clinical trials. Arch. Pharm. 2010, 343, 489-499.

286. Bar-Sela, G.; Epelbaum, R.; Schaffer, M. Curcumin as an anti-cancer agent: Review of the gap between basic and clinical applications. Curr. Med. Chem. 2010, 17, 190-197.

287. Bachmeier, B.E.; Killian, P.; Pfeffer, U.; Nerlich, A.G. Novel aspects for the application of Curcumin in chemoprevention of various cancers. Front Biosci. (Sch. Ed.) 2010, 2, 697-717.

288. Hossain, D.M.; Bhattacharyya, S.; Das, T.; Sa, G. Curcumin: The multi-targeted therapy for cancer regression. Front. Biosci. (Sch. Ed.) 2012, 4, 335-355.

289. Kanai, M.; Imaizumi, A.; Otsuka, Y.; Sasaki, H.; Hashiguchi, M.; Tsujiko, K.; Matsumoto, S.; Ishiguro, H.; Chiba, T. Dose-escalation and pharmacokinetic study of nanoparticle curcumin, a potential anticancer agent with improved bioavailability, in healthy human volunteers. Cancer Chemother. Pharmacol. 2012, 69, 65-70.

290. Naksuriya, O.; Okonogi, S.; Schiffelers, R.M.; Hennink, W.E. Curcumin nanoformulations: A review of pharmaceutical properties and preclinical studies and clinical data related to cancer treatment. Biomaterials 2014, 35, 3365-3383.

291. Sasaki, H.; Sunagawa, Y.; Takahashi, K.; Imaizumi, A.; Fukuda, H.; Hashimoto, T.; Wada, H.; Katanasaka, Y.; Kakeya, H.; Fujita, M.; et al. Innovative preparation of curcumin for improved oral bioavailability. Biol. Pharm. Bull. 2011, 34, 660-665.

292. Cheng, A.L.; Hsu, C.H.; Lin, J.K.; Hsu, M.M.; Ho, Y.F.; Shen, T.S.; Ko, J.Y.; Lin, J.T.; Lin, B.R.; Ming-Shiang, W.; et al. Phase I clinical trial of curcumin, a chemopreventive agent, in patients with high-risk or pre-malignant lesions. Anticancer Res. 2001, 21, 2895-2900.

293. Chainani-Wu, N.; Silverman, S., Jr.; Reingold, A.; Bostrom, A.; Mc Culloch, C.; Lozada-Nur, F.; Weintraub, J. A randomized, placebo-controlled, double-blind clinical trial of curcuminoids in oral lichen planus. Phytomedicine 2007, 14, 437-446.

294. Rai, B.; Kaur, J.; Jacobs, R.; Singh, J. Possible action mechanism for curcumin in pre-cancerous lesions based on serum and salivary markers of oxidative stress. J. Oral Sci. 2010, 52, 251-256.

295. Chainani-Wu, N.; Madden, E.; Lozada-Nur, F.; Silverman, S., Jr. High-dose curcuminoids are efficacious in the reduction in symptoms and signs of oral lichen planus. J. Am. Acad. Dermatol. 2012, 66, 752-760.

296. Polasa, K.; Raghuram, T.C.; Krishna, T.P.; Krishnaswamy, K. Effect of turmeric on urinary mutagens in smokers. Mutagenesis 1992, 7, 107-109.

297. Hastak, K.; Lubri, N.; Jakhi, S.D.; More, C.; John, A.; Ghaisas, S.D.; Bhide, S.V. Effect of turmeric oil and turmeric oleoresin on cytogenetic damage in patients suffering from oral submucous fibrosis. Cancer Lett 1997, 116, 265-269.

298. Sharma, R.A.; McLelland, H.R.; Hill, K.A.; Ireson, C.R.; Euden, S.A.; Manson, M.M.; Pirmohamed, M.; Marnett, L.J.; Gescher, A.J.; Steward, W.P. Pharmacodynamic and pharmacokinetic study of oral Curcuma extract in patients with colorectal cancer. Clin. Cancer Res. 2001, 7, 1894-1900. 
299. Garcea, G.; Jones, D.J.; Singh, R.; Dennison, A.R.; Farmer, P.B.; Sharma, R.A.; Steward, W.P.; Gescher, A.J.; Berry, D.P. Detection of curcumin and its metabolites in hepatic tissue and portal blood of patients following oral administration. Br. J. Cancer 2004, 90, 1011-1015.

300. Sharma, R.A.; Euden, S.A.; Platton, S.L.; Cooke, D.N.; Shafayat, A.; Hewitt, H.R.; Marczylo, T.H.; Morgan, B.; Hemingway, D.; Plummer, S.M.; et al. Phase I clinical trial of oral curcumin: Biomarkers of systemic activity and compliance. Clin. Cancer Res. 2004, 10, 6847-6854.

301. Garcea, G.; Berry, D.P.; Jones, D.J.; Singh, R.; Dennison, A.R.; Farmer, P.B.; Sharma, R.A.; Steward, W.P.; Gescher, A.J. Consumption of the putative chemopreventive agent curcumin by cancer patients: Assessment of curcumin levels in the colorectum and their pharmacodynamic consequences. Cancer Epidemiol. Biomark. Prev. 2005, 14, 120-125.

302. Cruz-Correa, M.; Shoskes, D.A.; Sanchez, P.; Zhao, R.; Hylind, L.M.; Wexner, S.D.; Giardiello, F.M. Combination treatment with curcumin and quercetin of adenomas in familial adenomatous polyposis. Clin. Gastroenterol. Hepatol. 2006, 4, 1035-1038.

303. Lao, C.D.; Ruffin, M.T.T.; Normolle, D.; Heath, D.D.; Murray, S.I.; Bailey, J.M.; Boggs, M.E.; Crowell, J.; Rock, C.L.; Brenner, D.E. Dose escalation of a curcuminoid formulation. BMC Complement. Altern. Med. 2006, 6, 10.

304. Vadhan-Raj, S.; Weber, D.; Wang, M.; Giralt, S.; Thomas, S.; Alexanian, R.; Zhou, X.; Patel, P.; Bueso-Ramos, C.; Newman, R.; et al. Curcumin downregulates NF-kB and related genes in patients with multiple myeloma: Results of a phase I/II study. Blood 2007, 110, 1177.

305. Dhillon, N.; Aggarwal, B.B.; Newman, R.A.; Wolff, R.A.; Kunnumakkara, A.B.; Abbruzzese, J.L.; $\mathrm{Ng}$, C.S.; Badmaev, V.; Kurzrock, R. Phase II trial of curcumin in patients with advanced pancreatic cancer. Clin. Cancer Res. 2008, 14, 4491-4499.

306. Golombick, T.; Diamond, T.H.; Badmaev, V.; Manoharan, A.; Ramakrishna, R. The potential role of curcumin in patients with monoclonal gammopathy of undefined significance-Its effect on paraproteinemia and the urinary N-telopeptide of type I collagen bone turnover marker. Clin. Cancer Res. 2009, 15, 5917-5922.

307. Bayet-Robert, M.; Kwiatkowski, F.; Leheurteur, M.; Gachon, F.; Planchat, E.; Abrial, C.; Mouret-Reynier, M.A.; Durando, X.; Barthomeuf, C.; Chollet, P. Phase I dose escalation trial of docetaxel plus curcumin in patients with advanced and metastatic breast cancer. Cancer Biol. Ther. 2010, 9, 8-14.

308. Epelbaum, R.; Schaffer, M.; Vizel, B.; Badmaev, V.; Bar-Sela, G. Curcumin and gemcitabine in patients with advanced pancreatic cancer. Nutr. Cancer 2010, 62, 1137-1141.

309. Ide, H.; Tokiwa, S.; Sakamaki, K.; Nishio, K.; Isotani, S.; Muto, S.; Hama, T.; Masuda, H.; Horie, S. Combined inhibitory effects of soy isoflavones and curcumin on the production of prostatespecific antigen. Prostate 2010, 70, 1127-1133.

310. Carroll, R.E.; Benya, R.V.; Turgeon, D.K.; Vareed, S.; Neuman, M.; Rodriguez, L.; Kakarala, M.; Carpenter, P.M.; McLaren, C.; Meyskens, F.L., Jr.; et al. Phase IIa clinical trial of curcumin for the prevention of colorectal neoplasia. Cancer Prev. Res. 2011, 4, 354-364.

311. Kanai, M.; Yoshimura, K.; Asada, M.; Imaizumi, A.; Suzuki, C.; Matsumoto, S.; Nishimura, T.; Mori, Y.; Masui, T.; Kawaguchi, Y.; et al. A phase I/II study of gemcitabine-based chemotherapy plus curcumin for patients with gemcitabine-resistant pancreatic cancer. Cancer Chemother. Pharmacol. 2011, 68, 157-164. 
312. Kim, S.G.; Veena, M.S.; Basak, S.K.; Han, E.; Tajima, T.; Gjertson, D.W.; Starr, J.; Eidelman, O.; Pollard, H.B.; Srivastava, M.; et al. Curcumin treatment suppresses IKKbeta kinase activity of salivary cells of patients with head and neck cancer: A pilot study. Clin. Cancer Res. 2011, 17, 5953-5961.

313. Chainani-Wu, N.; Collins, K.; Silverman, S., Jr. Use of curcuminoids in a cohort of patients with oral lichen planus, an autoimmune disease. Phytomedicine 2012, 19, 418-423.

314. Golombick, T.; Diamond, T.H.; Manoharan, A.; Ramakrishna, R. Monoclonal gammopathy of undetermined significance, smoldering multiple myeloma, and curcumin: A randomized, double-blind placebo-controlled cross-over $4 \mathrm{~g}$ study and an open-label $8 \mathrm{~g}$ extension study. Am. J. Hematol. 2012, $87,455-460$.

315. Ghalaut, V.S.; Sangwan, L.; Dahiya, K.; Ghalaut, P.S.; Dhankhar, R.; Saharan, R. Effect of imatinib therapy with and without turmeric powder on nitric oxide levels in chronic myeloid leukemia. J. Oncol. Pharm. Pract. 2012, 18, 186-190.

(C) 2015 by the authors; licensee MDPI, Basel, Switzerland. This article is an open access article distributed under the terms and conditions of the Creative Commons Attribution license (http://creativecommons.org/licenses/by/4.0/). 